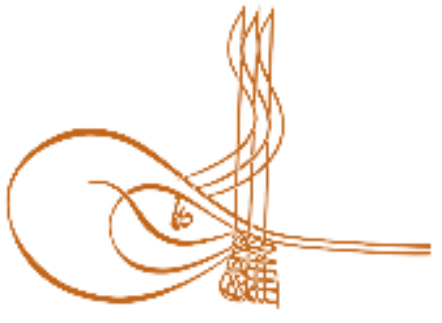

www.turkishstudies.net/social
Turkish Studies - Social Sciences

eISSN: $2667-5617$

Research Article / Araştırma Makalesi

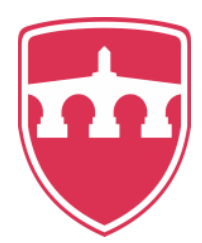

INTERNATIONAL

BALKAN

UNIVERSITY

Sponsored by IBU

\title{
Ağızdan Ağıza İletişimin Tüketicilerin Beyaz Eşya Satın Alma Kararları Üzerindeki Etkisi: Batman İli Örneği"
}

\author{
The Effect of Word of Mouth Communication on Consumers' Purchasing Decisions: (Example of \\ Batman Province)
}

\author{
Faruk Çiftçi ${ }^{* *}-$ Kazım Kılınç***
}

\begin{abstract}
In today's competitive environment, businesses and organizations want to become a leader in the target market or have a satisfactory market share in line with their goals. For this, they have to produce products and services that can meet the demands, needs and expectations of consumers and put them into the target market. In this respect, businesses or organizations need to understand consumers well and analyze their expectations and expectations in order to reach their visions. Recently, word-of-mouth communication, which has become increasingly important, has been recognized as a major cost-effective promotional activity for businesses or organizations. At this point, word-of-mouth communication is seen as an promotional activity by enterprises and organizations both in order to meet the demands, needs and expectations of the consumers and also to minimize their costs while doing these. In addition, it is of great importance that businesses and organizations give importance to word of mouth communication in order to keep their current customer portfolio and gain new customers, in order to understand the wishes and expectations of consumers. The main purpose of this study is to examine the effect of word-of-mouth communication on the white goods sector in consumers' purchasing decisions. In this context, the relationship between oral communication and consumer white goods purchasing decisions, which are among the information sources that consumers applied before making a purchase decision, are examined. The questionnaires prepared for this purpose were applied in Batman province. During the implementation process, the data obtained through surveys were recorded in statistical analysis data files. Statistical analysis such as reliability, validity, frequency, t-test and one-way ANOVA analysis were performed. As a result of the analyzes, it was revealed that there is a significant and positive relationship between consumers' decisions to purchase white goods and oral communication which is accepted as promotion and promotion technique.
\end{abstract}

\footnotetext{
* Makaledeki veriler 2019 yılının son çeyreğinde toplanmıştır.

*** Yüksek Lisans Öğrencisi, Batman Üniversitesi Sosyal Bilimler Enstitüsü İşletme Anabilim Dalı

Graduate Student, Batman University, Institute of Social Sciences, Department of Business

ORCID 0000-0002-8012-4606

ciftci.farukk@gmail.com

**** Dr. Öğr. Üyesi, Batman Üniversitesi, İktisadi ve İdari Bilimler Fakültesi, İşletme Bölümü

Asst. Prof. Dr., Batman University Faculty of Economics and Administrative Sciences, Department of Business

ORCID 0000-0003-4154-5245

kazim.kilinc@ batman.edu.tr

Cite as/ Atıf: Çiftçi F., Kılınç, K. (2020). Ağızdan ağıza iletişimin tüketicilerin beyaz eşya satın alma kararları üzerindeki etkisi: Batman ili örneği, Turkish Studies - Social, 15(3), 1059-1086. https://dx.doi.org/10.29228/TurkishStudies.41754

Received/Geliş: 13 February/Şubat 2020

Accepted/Kabul: 25 April/Nisan 2020

Copyright $(C)$ INTAC LTD, Turkey

Checked by plagiarism software

Published/Yayın: 30 April/Nisan 2020

CC BY-NC 4.0
} 
Structured Abstract: In conjunction with increasing product diversity, the factors such as increasing number of replacement products, increasing competition between enterprises, fast technological development and etc. reflect on the behaviors, preferences and habits of consumers. This forces enterprises to try very different activities, strategies and promotion techniques for presenting and delivering their products to consumers.

One of the biggest marketing combination elements, contributing the most in the success of enterprises, is publicity and promotion activities. In increasing competitive conditions, the enterprises in white appliances sector perform various publicity and promotion activities in order to have a larger market share than other competitor enterprises in the sector and become the enterprise which is firstly preferred by consumers. Within this regard, it is not sufficient for enterprises to produce any product and present it to market. It is extremely important for development and growth of enterprises that the products produced by enterprises are announced and introduced through various promotional activities in order these products to be preferable by consumers and reach their target audiences.

The budgets of enterprises allocated for their marketing strategies have been gradually expanding through increasing competition. The enterprises are directed to different promotional activities, especially as one of the elements of promotion mix, advertising is over-costing. At this point, word-of-mouth communication, which has become gradually important, is considered extremely important by enterprise as it is a cheap publicity and promotion activity and any product produced by enterprises is rapidly advertised through word-of-mouth communication.

In general, before making a purchasing decision, consumers prefer a product or service which they have previously used and experienced and if, they are willing to purchase a product or service which they do not have any detail on it, they refer to the source of information they consider most reliable. At this point, consumers act in accordance with the information provided by the ones among their friends and relatives they consider as their inner circle who have used or consumed this product or service. Some consumers make their decision in accordance with the information provided by other consumers who they believe that they are specialized on the product or service they are willing to purchase.

Today, access to information has become easier thanks to developments in communication. The consumers have lost their faith in the marketing activities referred by enterprises to as classical activities, as consumers have become much more aware through developments in communication. Within this respect, like every sector, in the white appliances sector, the information obtained through communication between consumers is considered more credible and more reliable from the advertisements and promotions controlled by enterprises. This is because, while, making a purchasing decision, they believe that the people in their inner circler are more honest, sincere, and progressive and experienced on the products or services they decide to purchase rather than various promotional marketing activities of enterprises. From this point of view, it is obvious that word-of-mouth communication is important in the white appliances sector just like for every sector.

In this study, the influence of word-of-mouth communication on decision of consumers for purchasing white appliances has been studied. It has been tried to determine whether consumers use of word-of-mouth communication for making their purchasing decisions or at what extend they use word-of-mouth communication while making such decisions, whether they take advice in their decision making process and the ones who they usually apply for taking advice on that, whether they recommend the products they are satisfied and finally whether they make any complaint against the enterprise where they purchase their products if, they are not satisfied with the product/service they purchase.

One of the purposes of the study is to research whether there is any meaningful difference or relation between demographical characteristics of consumers and word-of-mouth communication. T-test analysis has been conducted in order to determine whether word-of-mouth communication varies in accordance with the sex and marital status and white appliances purchasing methods of consumers. In addition, one-way analysis of variance has been implemented in order to determine whether there is any difference based on age, level of education, profession, using e-mail and social media tools, satisfaction of consumers related with their existing white appliances, the ones whom consumers take advice and the number of people they take advice, current white appliance replacement or purchasing status of them and finally whether there is any difference with regards to consumer evaluation. As a result of the conducted t-test and one-way analysis of variance, it has

Turkish Studies - Social, 15(3) 
been concluded that demographical characteristics of consumers have meaningful difference on word-of-mouth communication.

In accordance with the obtained data, it has been determined that the consumers willing to purchase the white appliance they have decided to buy from a second-hand white appliance dealers share their satisfaction or dissatisfaction in various social media platforms more than the consumers preferring to purchase their products from dealers selling unused white appliances. In addition to this, it has been determined that the consumers preferring to purchase second-hand white appliances take advices of people they do not know into account more than the consumers preferring to purchase their products from dealers selling unused white appliances. Moreover, it has been concluded that the participants preferring to purchase second-hand white appliances consider the advices of consumers who do not use the product they are willing to purchase. It has been determined that the married participants consider sufficient experience of the manufacturer enterprise of the white appliance they prefer more important than single participants. Furthermore, it has been determined that the married participants take advices into account more than single participants while choosing the products they are willing to purchase and they give more advices to their inner circle for purchasing the products they have purchased compared to single ones. It has been concluded that compared to female participants, male participants, before making a decision to purchase a white appliance, they give more advice to their relatives and when appropriate, everyone they know, when they are satisfied with a white appliance. In addition, it has been determined that male participants rely on the information provided by the ones using the same white appliance more than female participants. Moreover, it has been determined that male participants share their dissatisfaction they experience for the white appliances they prefer in social media (facebook, instagram, twitter and etc.), blogs or other complaint websites (Table 4).

Findings of the study (Table 6) have revealed that as the level of education before making a decision for purchasing white appliances rises, information provided by inner circle is considered more important. In addition, the participants with higher level of education consider it more important that the consumer they take advice has knowledge on the related white appliance and the white appliance brand to be chosen is a reputable and sufficiently experienced brand.

It has been observed that the civil servants and freelancers (Table 7) with high level of participation in the study consider the information they get from their circles imporant and they make purchasing decisions in accordance with the information provided by their inner circles.

As a result of the analyses, it has been determined that in general, the level of specialty of the person where the information is obtained related with the product has a significant influence on the level of impression on consumers through word-of-mouth communication. It has been found that most of the participants consider the information provided by their inner circles, relatives and friends more reliable and it is important that the high level of knowledge of the person providing the information on the product and being an experienced user are also considered important by consumers. It has also been concluded that participants apply to persons who have more expertise on the product they purchase. On the other hand, it has been concluded that the participants do not usually share their satisfaction or dissatisfaction related with the products they purchase in any social media platform.

In consideration of the collected data, it has been concluded that enterprises should focus on customer satisfaction by producing products to satisfy expectations and needs of their consumers. The enterprises in white appliances sector should attach more importance on word-of-mouth communication which is not one of the classical promotion and publicity techniques for gaining new customers and retaining the existing customer group. It is obvious that the enterprises attaching more importance on word-of-mouth communication which is a cost-efficient method of communication will take them a step forward and provide competitive advantage compared to their competitors. At this point, with reference to the motto "Every individual is a source of advice", it is considered that enterprises and organizations should take the following recommendations into their consideration if they are to take advantage from word-of-mouth communication to the maximum extent. Within this context; it is considered that word-of-mouth communication which is important for the most efficient promotion of goods and services, gaining new customers and establishing a loyal customer group should be included especially in promotion and publicity strategies of them. They can bring in new customers to their enterprises through opinion leaders and recommendations and guidance of them. By this way, in target markets, enterprises can convey the messages they would like to deliver consumers through opinion leaders. 
In order to prevent or minimize negative word-of-mouth communication, they should continuously follow the flow of information in their target market and create spaces to provide positive word-of-mouth communication.

They can send celebratory messages, flowers and etc. to the existing customers of enterprises in the sector in special days they consider important such as their birthdays and etc. By this way, it can be ensured that existing customers are considered important by the enterprise. Furthermore, it can be ensured that the current relations with existing customers are improved more by informing them through various promotional activities for them to keep informed about new services and services are recommended to different consumers by existing customers through word-of-mouth communication.

One of the issues considered the most important by consumers is after-sales services as white appliances usually have a long service life. Within this regard, the enterprises willing to increase their sales and improve their customer portfolio should attach great importance on after-sales services. The enterprises attaching due importance will pave the way for creating a satisfied customer group and it can be ensured that positive word-of-mouth communication is created for the enterprise.

In the frame of this study, it is considered that it will be advantageous to conduct future studies in various sectors and larger samples. The subject of the study is white appliances product group. Various product groups can be considered as a subject of a different study. It is considered to provide contribution in the enterprises in white appliances sector and the literature through this study.

Keywords: Word-of-Mouth communication, Consumer Behaviors, White Appliances Sector

Öz: Günümüz rekabet ortamında işletme ve organizasyonlar hedef pazarda lider konuma gelebilmek veya hedefleri doğrultusunda tatmin edici bir pazar payına sahip olmak istemektedirler. Bu açıdan işletme veya organizasyonların vizyonlarına ulaşabilmek adına tüketicileri iyi anlamaları istek ve beklentilerini iyi analiz etmeleri gerekmektedir. Bu doğrultuda son zamanlarda giderek önem kazanan ağızdan ağıza iletişim, işletme ve organizasyonlar için düşük maliyetli önemli büyük bir tanıtım ve tutundurma faaliyeti olarak kabul edilmektedir. Bu noktada ağızdan ağıza iletişim, işletme ve organizasyonlar tarafindan hem tüketicilerin istek, ihtiyaç ve beklentilerine cevap verebilmek adına hem de bunları yaparken de maliyetlerini minimize etmelerini sağlayacak bir tutundurma faaliyeti olarak görmektedirler. Ayrıca işletme ve organizasyonların mevcut müşteri portföyünü elde tutmak ve yeni müşteriler kazanabilmek için ağızdan ağıza iletişime gereken önemi vermeleri tüketicilerin istek ve beklentilerini anlamaları açısından da büyük önem arz etmektedir. Yapılan bu çalışmanın temel amacı, tüketicilerin satın alma kararlarında ağızdan ağıza iletişimin beyaz eşya sektöründeki etkisini incelemektir. Bu doğrultuda tüketicilerin satın alma kararı vermeden önce başvurmuş oldukları bilgi kaynakları arasında yer alan ağızdan ağıza iletişim ile tüketicilerin beyaz eşya satın alma kararları arasındaki ilişki irdelenmiştir. Bu amaçla hazırlanmış olan anketler Batman ilinde uygulanmıştır. Uygulama sürecinde anketler aracılığıyla elde edilen veriler istatistiki analiz veri kütüklerine işlenmiştir. Güvenirlik, geçerlik, frekans, $t$ testi ve tek yönlü varyans (anova) analizi gibi istatistiki analizler yapılmıştır. Yapılan analizler sonucunda, tüketicilerin beyaz eşya satın alma kararları ile tanıtım ve tutundurma tekniği olarak kabul edilen ağızdan ağıza iletişim arasında anlamlı ve pozitif yönlü bir ilişki olduğu ortaya konulmuştur.

Anahtar Kelimeler: Ağızdan Ağıza İletişim, Tüketici Davranışları, Beyaz Eşya Sektörü

\section{Giriș}

Genel olarak tüketiciler satın alma kararı vermeden önce, kimi zaman daha önce kullanıp deneyimledikleri mal veya hizmeti tercih ederken kimi zaman da bilgi sahibi olmadıkları bir malı veya hizmeti satın almak istediklerinde, kendilerince en güvenilir buldukları bilgi kaynağına başvurmaktadırlar. Bu noktada tüketiciler, yakın çevre olarak kabul ettikleri arkadaş ve akrabaları arasında daha önce bu mal veya hizmeti kullananlardan ya da tüketenlerden gelen bilgiler doğrultusunda hareket etmektedirler. Bazı tüketiciler ise satın almak istediği mal veya hizmetle ilgili uzman olduğuna inandıkları diğer tüketicilerin vermiş olduğu bilgiler ışığında karar vermektedirler.

Son yıllarda rekabetin artış göstermesiyle birlikte teknolojinin gelişmesi, mal ve hizmetlerin çeşitliliğini beraberinde getirmiştir. Ayrıca tüketicilerin istek ve beklentilerinin sürekli olarak 
değişkenlik gösterip artması, rekabet ortamında önemli bir rekabet avantajı elde etmek isteyen işletme veya organizasyonları, tüketicilerin istek ve beklentilerine cevap verebilecek mal veya hizmetlerin üretmesine itmektedir. $\mathrm{Bu}$ açıdan bir tanıtım ve tutundurma tekniği olarak kabul edilen ağızdan ağıza iletişim, tüketicilerin satın alma kararlarındaki etkisi çeşitli faktörlere bağlı olarak değişkenlik gösterebilmektedir. Bilgi paylaşımında bulunan tüketici ile bilgi alan tüketicinin hem kişilik özellikleri hem de mal veya hizmetlerle ilgili deneyimleri farklılık gösterebileceğinden satın alma kararlarını önemli ölçüde etkileyebilmektedir.

$\mathrm{Bu}$ çalışma ile tüketicilerin ağızdan ağıza iletişimin beyaz eşya satın alma kararlarına etkisi araştırılmıştır. Tüketicilerin satın alma tercihlerinde ağızdan ağıza iletişimden faydalanıp faydalanmadıkları ya da ne derecede faydalandıkları; satın alma karar sürecinde tavsiye alıp almadıkları ile genellikle kimlerden tavsiye aldıkları, memnun kaldıkları ürünleri tavsiye edip etmedikleri ve son olarak memnun kalmadıkları durumda ürününü satın aldıkları işletmeyi şikâyet edip etmedikleri belirlenmeye çalışılmıştır.

\section{Literatür}

\subsection{Ağızdan Ağıza İletişim}

Araştırmacılar tarafindan ağızdan ağıza iletişim kavramı üzerine uzun yıllardır çalışmalar yapılmasına rağmen ağızdan ağıza iletişim kavramı, 1900'lü yılların ikinci çeyreğinden itibaren modern pazarlama araştırmalarında yer bulmaya başlamıştır (Buttle, 1998: 241).

Ağızdan ağıza iletişim kavramı, tüketicilerin satın alma kararlarına etki etmekte önemli bir rol oynayan sosyo-psikolojik etmenler başta olmak üzere birçok etmenle ifade edebilecek çok boyutlu özelliklere sahip bir kavramdır. Ayrıca ağızdan ağıza iletişimin tüketicilerin satın alma kararları ve tercihleri üzerinde etkisinin olduğu gibi mal veya hizmetlerle ilgili olarak sahip oldukları tutum ve algılarına yön veren bir kavramdır (Tayfun vd., 2013: 27).

İnformal bir iletişim biçimi olarak kabul edilen ağızdan ağıza iletişim, işletmelerin üretmiş oldukları herhangi bir mal veya hizmetle ilgili olarak tüketicilerin kendi aralarında ve işletmelerden bağımsız bir ortamda sözlü iletişimde bulunmalarıdır. Tüketiciler arasında geçekleşen iletişim neticesinde mal veya hizmetlere yönelik olarak bir tüketicinin diğer tüketici ya da tüketici gruplarını satın alma veya satın almama konusunda ikna etme çabası olarak değerlendirilmektedir (Silverman, 2001: 25). Ağızdan ağıza iletişimi, aile üyeleri, arkadaşlar ve mevcut ya da potansiyel tüketiciler gibi gruplar arasında olumlu veya olumsuz diyaloglar şeklinde de tanımlanmak mümkündür (Avcılar, 2005: 333-347).

Ağızdan ağıza iletişimin çeşitlilik göstermesi, tüketicilerin fizyo-biyolojik olarak birbirilerinden farklı olmalarından ileri gelmektedir. Çünkü tüketim sürecinde tüketicilerin fizyobiyolojik yapılarının farklı olmasından dolayı karşılaşmış oldukları olumlu ya da olumsuz değerlendirmeler de farkl1lık gösterebilmektedir (Susskind, 2002: 75).

Olumlu (pozitif yönlü) olarak kabul edilen ağızdan ağıza iletişim, bir tüketicinin bir mal ya da hizmeti satın almadan önce yakın çevresindeki tüketicilerden olumlu tavsiyeler alması veya çevresinde bulunan tüketiciler tarafindan mal veya hizmet hakkında olumlu bilgiler verilmesi olarak değerlendirilebilir. Diğer taraftan daha önce satın almış olduğu bir ürünle ilgili olarak elde etmiş olduğu olumsuz deneyimleri aynı mal ya da hizmeti satın alma eğiliminde olan başka bir tüketiciye aktarma, olumsuz tutum takınmasına sebebiyet verecek şekilde paylaşımda bulunma ise olumsuz (negatif yönlü) ağızdan ağıza iletişim olarak kabul edilebilir. Bu bağlamda, pozitif yönlü ağızdan ağıza iletişim, mal ya da hizmeti üreten şirketlere olumlu yönde yansırken, negatif yönlü ise olumsuz yansımaktadır (Liu, 2006: 74-89).

Ağızdan ağıza iletişimin, geçmişten bugüne insanların satın alma davranışlarına yön veren, etki eden önemli bir faktör olduğu bilinmektedir. Genel olarak insanlar, kişisel bilgi kaynaklarını 
reklam vb. diğer bilgi kaynaklarından daha gerçekçi ve daha dürüst bir bilgi kaynağı olarak görmektedirler. Bir tüketicinin satın alma eğiliminde olduğu bir mal veya hizmet ile ilgili olarak reklamlar ya da satıcılardan gelen bilgilerden ziyade yakın çevrelerinden gelen bilgiler doğrultusunda hareket etmesi, söz konusu durumu açıklayıcı bir örnek olarak verilebilir (Odabaşı ve Oyman, 2006: 28).

Tüketiciler, iletişimde bulundukları kişi veya kişileri, bir marka ya da şirketten tamamen bağımsız ve genellikle güven duydukları insanlar olmaları nedeniyle, ağızdan ağıza iletişimi satın alma kararlarına etki eden diğer faktörlerden daha güvenilir görmelerini sağlamıştır (Derbaix ve Vanhamme, 2003: 100).

Ağızdan ağıza iletişimde geribildirim ve açıklama firsatı bulunduğundan, medya iletişim araçları olarak adlandırılan iletişim araçlarından daha büyük bir etkiye sahiptir. Bununla birlikte ağızdan ağıza iletişim yoluyla gelen tavsiyelerin inandırıcılığı ve güvenirliği daha fazla sağladığı düşünülmektedir (Day, 1971: 31).

Ağızdan ağıza iletişimin önemi, genellikle ağızdan ağıza iletişim tarafından etkilenen tüketici tercihlerinden, tüketiciler tarafından özellikle önemli kabul edilen satın alma durumlarından ve tüketicileri daha çok etkilediği gerçeğinden ileri gelmektedir. Çünkü tüketiciler, satın alma durumlarında genellikle işletmelerden bağımsız bilgilerden daha çok kişisel bilgilere güvenmektedirler (Balanche vd., 2010: 172).

Ağızdan ağıza iletişim tüketicilerin satın alma davranışları üzerinde reklam ve diğer tutundurma kaynaklarına göre daha etkin bir role sahip olmasına rağmen şirket ve organizasyonlar tarafından en çok göz ardı edilen tanıtım ve tutundurma tekniği olmaktadır. Fakat son zamanlarda işletme ve organizasyonlarca objektif ve bağımsız olması, bir deneyim paylaşım tekniği olması, hızı ve içeriğinin sınırsız olması ve tüketicilere zaman kazandırması gibi sebeplere bağlı olarak daha fazla önemsenmektedir ( Silverman, 2001: 38). Bu açıdan ağızdan ağıza iletişim, işletmeler tarafindan herhangi bir tüketicinin daha önce satın almış olduğu mal ve hizmetlere bağlı olarak tekrar satın alma niyeti üzerinde ve müşteri sadakati oluşturmada etkisi olan önemli bir boyut olarak görülmektedir. Ayrıca ağızdan ağıza iletişimin tüketicilerin eylem ve algılarını etkileme gücünün, hizmet sunucu ve alıcı arasındaki ilişkinin niteliğine, zenginliğine ve gücüne bağlı olduğu bilinmektedir (Kitapci, Akdoğan ve Dörtyol, 2014: 161-169).

Herhangi bir tüketicinin tekrar satın alma niyeti üzerinde, ağızdan ağıza iletişimde tavsiye, önemli bir değişken olarak kabul edilmektedir. Bunun nedeni ise tüketicinin daha önce tecrübe etmiş olduğu mal veya hizmetle ilgili olarak duymuş olduğu memnuniyetin yoğunluğunun yakın çevresinden almış olduğu tavsiyenin yoğunluğuna göre değişkenlik göstermesinden ileri gelmektedir. Bu durum tüketicilerde oluşan memnuniyet ya da memnuniyetsizlik ile tekrar satın alma arasındaki ilişkinin çok basit olmadığını ortaya koymaktadır (Lee, 2005: 157-167).

Beyaz eşya sektöründe faaliyet gösteren birçok işletme ve organizasyon, tüketici tercih ve beklentilerindeki değişiklik, teknolojik yenilik ve gelişmişliğe bağlı olarak her geçen gün artan yoğun rekabet ile karşı karşıya kalmaktadırlar. Yoğun rekabet ise işletme ve organizasyonları varlı̆̆ını sürdürmek, hedef pazarda lider konuma gelebilmek veya pazar payını artırma adına birçok tutundurma faaliyetine başvurmak zorunda bırakmaktadır. Bu açıdan işletme ve organizasyonlar hedeflerine ulaşabilmek için birçok tanıtım ve tutundurma faaliyetinden faydalanmak zorunda kalmaktadırlar. Bu zorunlulukla beraber, aynı zamanda elde etmiş oldukları kârları yüksek maliyetli tutundurma faaliyetlerine harcamak istememektedirler. Bu bağlamda işletme ve organizasyonlar bir tanıtım ve tutundurma tekniği olarak kabul edilen ve giderek öneminin artmakta olduğu ağızdan ağıza iletişimi tercih etmektedirler. İşletme ve organizasyonlar tarafindan tercih edilen ağızdan ağıza iletişim, hedef pazara yönelirken işletme ve organizasyonlara hem maliyet açısından avantaj sağlamakta hem de mal ve hizmetleri daha etkin bir şekilde tanıtıma imkânı tanımaktadır. Bu durum 
ağızdan ağıza iletişimin birçok sektörde olduğu gibi beyaz eşya sektöründe de önemini gözler önüne sermektedir (www.beysad.org.tr, 2019).

\subsection{Konuyla İlgili Yapılmış Çalışmalar}

Yapılan literatür taramasında, ağızdan ağıza iletișimin tüketicilerin satın alma davranışları ve tüketici tercihlerine etkisi üzerine yapılmış birçok çalışmanın olduğu görülmüştür. Çalışmaların genelinde bir tüketicinin bir mal veya hizmeti tercih etmesi, satın alması veya mal ve hizmetler ile ilgili bilgilerin yayılması üzerinde ağızdan ağıza iletişimin etkili olduğu sonuçlarına ulaşıldığı görülmüştür (Berger ve Iyenger, 2013: 567-579).

Ismail ve Melewar (2015) tarafindan yapılan çalışma ile ağızdan ağıza iletişimin hem tüketiciler hem de üreticiler için büyük önem taşıyan marka kimliği ve kişiliği üzerindeki etkisi belirlenmeye çalışılmıştır. Elde edilen bulgulardan, ağızdan ağıza iletişimin marka imajı, kimliği ve kişiliği üzerinde anlamlı bir etkisinin olduğu sonucuna ulaşılmıştır. Diğer bir çalışma ise Gürler ve Erturgut (2018) tarafından yapılmıştır. Yapılan çalışma ile kadın ve erkeklerin almış oldukları hizmetin kalitesine yönelik algılarının tatmin düzeyleri ile ağızdan ağıza iletişim faaliyetleri üzerinde anlamlı bir etkisinin olup olmadığı incelenmiştir. Yapılan çalışma neticesinde kadın katılımcıların daha çok güvenirlik boyutuna erkeklerin ise fiziksel görünüm boyutuna yönelik algılarının, ağızdan ağıza iletişim faaliyetleri üzerinde pozitif yönlü bir etkisinin olduğu sonucuna ulaşılmıştır.

Akçi ve Kılınç (2015) tarafından yapılan çalışma ile muhasebe meslek mensuplarının mevcut müşteri portföyünü arttırma konusunda ağızdan ağıza iletişimin olumlu ya da olumsuz bir etkisinin olup olmadığı belirlenmeye çalışılmıştır. Ağızdan ağıza iletişimin müşteri portföyünü arttırma konusunda pozitif etkilerinin olduğu sonucu elde edilmiştir. Uygun, Mete ve Güner (2014) ise tüketicilerin ağızdan ağıza iletişim tutumlarına yönelik alışveriş istekleri ile eğilimleri arasındaki ilişkiyi tespit etmek amacıyla yapmış oldukları çalışmada, tüketicilerin alışveriş istekleri ile ağızdan ağıza iletişim tutumları arasında bir ilişkinin olduğu sonucuna varmışlardır. Uzmanlık gerektiren çeşitli küçük ölçekli hizmet işletmelerince tüketicilere sunulan kişisel bakım gibi hizmetlerin tüketiciler tarafindan tercih edilmesinde ağızdan ağıza iletişimin etkili olup olmadığı belirlenmesi amacıyla Kılınç (2017) tarafından yapılmış olan çalışmada, tüketicilerin ağızdan ağıza iletişimin büyük ölçüde hizmet alımına ve işletme tercihine etkisinin olduğu sonucuna ulaşılmıştır.

Lang (2015) ağızdan ağıza iletişim ile tüketicilerin belli bir mal veya hizmetle ilgili memnuniyetleri arasındaki ilişkiyi irdelemek amacıyla bir çalışma yapmıştır. Yapılan çalışma sonucunda memnun olmayan müşterilerin memnun olan müşterilere nazaran daha fazla ağızdan ağıza iletişime yöneldikleri sonucuna varılmıştır. İşletmelerin üretmiş olduğu ürünlerin kalitesi ile ağızdan ağıza iletişim arasındaki denge ilişkisini irdelemek amacıyla Godes (2016) tarafindan yapılan çalışmada, ağızdan ağıza iletişim kitlesi büyüdükçe ürünlerin kalitesini arttırabileceği gibi tersi bir durumun da olabileceği sonucuna ulaşılmıştır. Balajı, Roy ve Lassar (2017) ise bankacılık hizmetlerinde ağızdan ağıza iletişim ile dil farklılığının arasında bir ilişkinin olup olmadığı belirlenmeye çalışılmıştır. Ağızdan ağıza iletişimde dil ayrılığı ile perakende bankacılık hizmetleri arasında bir ilişkinin olduğu tespit edilmiştir.

Roy, Butaney, Sekhon ve Butaney (2014) tarafindan yapılan çalışmada, tüketicilerin işletmeye sadakatleri ile ağızdan ağıza iletişim arasında bir ilişkinin söz konusu olup olmadığı irdelenmiştir. Çalışma sonucunda tüketicilerin ürününü tükettiği işletmeyle duygusal bağl1lıklarının artmasının, ağızdan ağıza iletişimden büyük ölçüde etkilendiği ortaya konulmuştur. Mıkalef, Patelı ve Gıannakos (2013) ise sosyal medyada ağızdan ağıza iletişimin tüketicilerin hem hedonik hem de faydacı kuramlara dayalı motivasyonlarını aydınlatmak amacıyla bir çalışma yapmışlardır. Yapmış oldukları çalışma sonucunda gerek hedonik kuramların gerekse de faydacı kuramların ağızdan ağıza iletişimi etkilediği sonucuna ulaşmışlardır. 


\section{Araştırmanın Metodolojisi}

\subsection{Araştırmanın Konusu, Amacı ve Problemi}

Günümüzde yaşanan değişim ve gelişimler, insanların tüketim alışkanlıklarının değişimini de beraberinde getirmiştir. Bu değişimler tüketicilerin istek ve arzularına da yansıdığından tüketicilerin, işletmelerin pazara sunmuş oldukları mal ve hizmetlerden beklentileri artmıştır. Artan beklentiler ise işletmeleri yoğun rekabet ortamında, varlıklarının devamı açısından tüketicilerin beklentilerine cevap verebilmek adına değişim sürecine uymaya zorlamıştır. $\mathrm{Bu}$ zorunluluk ișletmeleri başarı elde edebilmek için yeni arayıșlar içerisine girmeye, yeni satış, tanıtım ve tutundurma tekniklerinden faydalanmaya yönlendirmiştir. Bu açıdan araştırmanın konusu, rekabet içerisinde olan işletmelerin zamanla önem kazanan ve bir tanıtım ve tutundurma tekniği olarak kabul edilen ağızdan ağıza iletişimin tüketicilerin beyaz eşya satın alma kararlarındaki etkisini ortaya koymaktır.

Araştırmanın amacı ise, her geçen gün pazarlama bilimi açısından giderek önem kazanan ağızdan ağıza iletişimin beyaz eşya sektöründe tüketicilerin satın alma kararlarına ne derecede etkili olduğu, tüketicilerin satın alma kararlarını ne şekilde etkilediği ve yönlendirdiğine yönelik olarak tespitte bulunmaktır.

Rekabet içerisinde olan işletme ve organizasyonların hedef pazarda rakiplerine üstünlük sağlayabilmek adına farklı tutundurma faaliyetlerini kullanarak büyük bir pazar payına sahip olabilmek istemeleri, işletme ve organizasyonlar açısından problem oluşturmaktadır. İşletme veya organizasyonların rakiplerine yönelik üstünlük sağlayabilmeleri adına tüketici davranışlarını göz ardı etmeyerek incelemeleri, tüketici davranışlarına yönelik çalışmalar yapmaları ve bunlara ek olarak tüketicilerin istek ve beklentilerini karşılayacak adımlar atmaları söz konusu problemin çözümü adına büyük bir önem arz etmektedir. Bu açıdan araştırmanın problem cümlesi; "Bireylerin beyaz eşya satın alma kararında ağızdan ağıza iletişimin etkisi var mıdır?" şeklinde belirlenmiştir. Belirlenen problem cümlesine bağlı olarak ağızdan ağıza iletişimin bireylerin beyaz eşya satın alma kararlarında etkili olup olmadığı, ne derecede etkili olduğu, bireylerin satın alma kararı öncesinde ağızdan ağıza iletişimden faydalanıp faydalanmadıkları sorularına cevap aranmaya çalışılmıştır.

\subsection{Evren ve Örneklem}

Batman ili ve ilçelerinde bulunan tüketiciler araştırma evrenini oluşturmuştur. 05.06.2019 tarihi itibariyle Batman ili ve ilçelerindeki nüfusun 599.103 olduğu belirlenmiştir. Örneklem ise olasılığa dayalı olmayan örnekleme yöntemlerinden kolayda örnekleme yöntemi ile belirlenmiştir. $\% 95$ güven aralığ 1 ve $\% 5$ hata payında 384 adet anket verisi yeterliyken güven aralığının arttırılması için 516 anket uygulanmıştır. Bu büyüklükteki örneklemin evreni yeterli derecede temsil edeceği varsayılmıştır.

\section{3. Ölçek ve Ölçek Geliştirme Süreci}

Araştırmada, Batman ili ve ilçelerindeki tüketicilerin beyaz eşya tercihlerinde ağızdan ağıza iletişimden ne ölçüde faydalandıklarını belirlemek amacı ile objektif verilerin elde edilebilmesi ve ölçülüp yorumlanabilmesi açısından, birinci derece veri toplama yöntemi olarak değerlendirilen anket yöntemi kullanılmıştır.

Anket formu oluşturulurken Kılınç (2017) "Üniversite Öğrencilerinin Kuaför Tercihinde Ağızdan Ağıza İletişimin Etkisinin İncelenmesi” adlı çalışmasından faydalanılmıştır. Oluşturulan anket formu iki bölümden oluşmaktadır. Birinci bölümde, demografik bilgiler (yaş, meslek, eğitim vb.), elektronik iletişim kullanımı (e-mail, twitter vb. 2 madde / çoktan seçmeli), mevcut beyaz eşya ürününe ilişkin düşünceler (5 madde / çoktan seçmeli) ve tüketici ve kişisel değerlendirme soruları (2 madde / çoktan seçmeli) yer almaktadır. İkinci bölümde ise ağızdan ağıza iletişim ile ilgili düşünceleri ortaya koyan ifadelere (30 madde / beşli likert) yer verilmiştir. 
Soruların hem anlaşılabilir olup olmadığını hem de eksikliklerinin belirlenip giderilmesi amaciyla anket, 75 kişilik bir pilot uygulamaya tabi tutulmuştur. Pilot uygulamanın Cronbach's Alpha değeri $(0,818)$ olarak bulunmuştur. Bulunan değer güvenilir olarak kabul edildiğinden ana uygulamaya geçilmiştir. Ayrıca yapı geçerliliğinin kontrolü amacıyla faktör analizi yapılmıştır. Analiz sonucunda KMO değerinin 0,893 ve anlamlılık değerinin ise 0,000 olduğu görülmüştür. Yapılan söz konusu analiz ölçülmek istenen yapının uyumlu olduğu sonucunu ortaya koymaktadır.

\subsection{Verilerin Analizi}

İlk aşamada, elde edilen verilerin geçerlik ve güvenirlik analizleri yapılmış, geçerlik ve güvenirlik kontrolü sağlandıktan sonra demografik değişkenlere ilişkin bulgular ile e-mail ve sosyal medya kullanımına ilişkin istatistiki veriler belirlenmiştir. Ayrıca, ankete katılan tüketicilerin mevcut beyaz eşyalarını ne durumda değiştirdikleri, beyaz eşya tercihleri, mevcut beyaz eşyalarından memnuniyetleri ve tavsiye alma bulguları istatistiki olarak tespit edilmeye çalışılmıştır. Verilerin incelenmesi amacıyla ortalama ve frekans dağılımı analizleri ile birlikte T testi ve tek yönlü varyans (anova) analizleri yapılmıştır.

Tablo 1: Demografik Veriler, E-Mail ve Sosyal Medya Kullanımına İlişkin Bulgular

\begin{tabular}{|c|c|c|c|c|c|}
\hline Cinsiyet & Frekans & Yüzde (\%) & Yaş & Frekans & Yüzde (\%) \\
\hline Kadın & 247 & 47,9 & 25'ten küçük & 146 & 28,3 \\
\hline Erkek & 269 & 52,1 & $25-35$ aras 1 & 222 & 43,0 \\
\hline \multirow[t]{4}{*}{ Toplam } & 516 & 100,0 & $36-45$ aras1 & 93 & 18,0 \\
\hline & & & $46-55$ aras 1 & 46 & 8,9 \\
\hline & & & 56 ve üstü & 9 & 1,7 \\
\hline & & & Toplam & 516 & 100,0 \\
\hline $\begin{array}{l}\text { Medeni } \\
\text { Durum }\end{array}$ & Frekans & Yüzde (\%) & $\begin{array}{l}\text { Eğitim } \\
\text { Durumu }\end{array}$ & Frekans & Yüzde (\%) \\
\hline Evli & 282 & 54,7 & İlköğretim & 77 & 14,9 \\
\hline Bekâr & 234 & 45,3 & Lise & 140 & 27,1 \\
\hline \multirow[t]{3}{*}{ Toplam } & 516 & 100,0 & Ön Lisans & 122 & 23,6 \\
\hline & & & Lisans ve Üstü & 177 & 34,3 \\
\hline & & & Toplam & 516 & 100,0 \\
\hline Meslek & Frekans & Yüzde (\%) & E-Mail & Frekans & Yüzde (\%) \\
\hline Memur & 235 & 45,5 & Yok & 141 & 27,3 \\
\hline İşçi & 58 & 11,2 & Günlük & 134 & 26,0 \\
\hline Özel Sektör & 51 & 9,9 & Haftalık & 109 & 21,1 \\
\hline $\begin{array}{l}\text { Serbest } \\
\text { Meslek }\end{array}$ & 164 & 31,8 & Aylık & 132 & 25,6 \\
\hline Emekli & 8 & 1,6 & Toplam & 516 & 100,0 \\
\hline \multirow[t]{6}{*}{ Toplam } & 516 & 100,0 & Sosyal Medya & Frekans & Yüzde (\%) \\
\hline & & & Kullanmiyorum & 162 & 31,4 \\
\hline & & & Günlük & 234 & 45,3 \\
\hline & & & Haftalık & 66 & 12,8 \\
\hline & & & Aylik & 54 & 10,5 \\
\hline & & & Toplam & 516 & 100,0 \\
\hline
\end{tabular}

Tablo 1 incelendiğinde katılımcıların \%47,9'nun kadınlardan; \%52,1'nin ise erkeklerden oluştuğu görülmektedir. Anket formunu cevaplayan 516 katılımcının $\% 28,3$ 'nün 25 ve 25 yaşından küçük olduğu, \%43'nün 25 ile 35 arasında, \%18'nin 36 ile 45 arasında, \%8,9'nun 46 ile 55 arasında olduğu ve sadece \%1,7'sinin 56 ve 56 yaşından büyük katılımc1lar olduğu belirlenmiştir.

Araştırmaya katılan tüketicilerin \%54,7'si evliyken \%45,3'ü evli olmadığı görülmektedir. Ayrıca katılımcıların \%14,9'u ilköğretim, \%27,1'i lise, \%23,6's1 ön lisans, \%34,3’ü ise lisans ve 
lisansüstü mezunu olduğu belirlenmiştir. Kat1lımcıların \%45,5'nin memur, \%11,2'nin işçi ve \%1,6'nın emekli olduğu, bunların yanında katılımcıların \%9,9'nun özel sektörde çalıştıkları \%31,8'nin ise serbest meslek sahibi oldukları anlaşılmıştır. Ayrıca tablodan katılımcıların e-mail kullanımlarına ilişkin dengeli bir dağılım gerçekleşmiş olup birbirine yakın değerler aldığı görülmektedir. Bu değerler; e-mailim yok kullanmıyorum cevabını veren katılımcılar, katılımcıların $\% 27,3$ 'ünü, e-mail kullanıp günlük kontrol edenler katılımcıların \%26'sını, haftalık kontrol edenler $\% 21,1$ 'ini oluştururken \%25,6'sını ise aylık kontrol edenler oluşturmaktadır. Sosyal medya kullanımına ilişkin bulgulara bakıldığında ise katılımcıların \%31,4'nün sosyal medyayı kullanmadıkları, \%45,3'nün sosyal medyayı kullandıkları ve günlük kontrol ettikleri, \%12,8'nin haftalık kontrol ettikleri ve son olarak katılımcıların \%10,5'nin aylık kontrol ettikleri tespit edilmiştir.

Tablo 2: Tavsiye, Satın Alma ve Değiştirme Durumu, Memnuniyet ve Satın Alma Şekline

\begin{tabular}{|c|c|c|c|c|c|}
\hline Tavsiye & Frekans & $\frac{\text { Bulgu }}{(\%)}$ & Memnuniyet & Frekans & $(\%)$ \\
\hline Arkadaşlarımın tavsiyesi & 118 & 22,9 & $\begin{array}{l}\text { Hiç memnun } \\
\text { değilim }\end{array}$ & 34 & 6,6 \\
\hline Akrabalarımın tavsiyesi & 116 & 22,5 & Memnun değilim & 44 & 8,5 \\
\hline Uzman kişilerin tavsiyesi & 159 & 30,8 & Kararsızım & 68 & 13,2 \\
\hline $\begin{array}{l}\text { Sosyal medyadaki } \\
\text { tavsiyeler }\end{array}$ & 30 & 5,8 & Memnunum & 315 & 61,0 \\
\hline $\begin{array}{l}\text { Satıcinın tavsiyesi } \\
\text { Toplam }\end{array}$ & $\begin{array}{c}93 \\
516\end{array}$ & $\begin{array}{c}18,0 \\
100,0\end{array}$ & $\begin{array}{l}\text { Çok memnunum } \\
\text { Toplam }\end{array}$ & $\begin{array}{c}55 \\
516\end{array}$ & $\begin{array}{c}10,7 \\
100,0\end{array}$ \\
\hline $\begin{array}{l}\text { Satın Alma ve } \\
\text { Değiştirme Durumu }\end{array}$ & Frekans & $(\%)$ & Satın Alma Şekli & Frekans & $(\%)$ \\
\hline $\begin{array}{l}\text { Sadece İhtiyaç } \\
\text { Duyduğumda }\end{array}$ & 234 & 45,3 & Sifir & 469 & 90,9 \\
\hline $\begin{array}{l}\text { Mevcut beyaz eşyanın } \\
\text { bozulması durumunda }\end{array}$ & 128 & 24,8 & İkinci el & 47 & 9,1 \\
\hline $\begin{array}{l}\text { Bozulan beyaz esyanın } \\
\text { tamir edilememesi } \\
\text { durumunda }\end{array}$ & 133 & 25,8 & Toplam & 516 & 100,0 \\
\hline $\begin{array}{l}\text { Daha üst bir model } \\
\text { çiktığında }\end{array}$ & 21 & 4,1 & & & \\
\hline Toplam & 516 & 100,0 & & & \\
\hline
\end{tabular}

Veriler incelendiğinde katılımcıların \%50’ye yakınının yakın çevrelerinden almış oldukları tavsiyeler doğrultusunda satın alma kararı verdikleri görülmektedir. Sosyal medya platformlarında yer alan tavsiyeleri genellikle dikkate almadıkları tablodan anlaşılırken, \%30,8'nin ise uzman olduğuna inandığı kişilerin tavsiyelerini de göz ardı etmedikleri ve bu yönde satın alma kararı aldıkları anlaşılmaktadır.

Tavsiye alma sayısı konusunda veriler incelendiğinde genellikle katılımcıların \%28,5'nin beyaz eşya satın alma kararı almadan önce hiç tavsiye almadıkları tespit edilmiştir. Bu durumda katılımcıların kendi bilgi ve deneyimlerine göre satın alma kararı aldıkları sonucunu çıkarmak mümkündür. Diğer taraftan katılımcıların yarısından fazlasının $(\% 66,6)$ en az iki kişiden olmak kaydıyla üç, dört ve daha fazla kişiden tavsiye aldıkları anlaşılmaktadır. Bunlarla birlikte katılımcıların çok azının ( $\% 8,9)$ sadece bir kişiden tavsiye aldığı görülmektedir.

Katılımcıların yarısından fazlasının (\%61) mevcut beyaz eşyalarından memnun oldukları anlaşılmaktadır. Tablo incelendiğinde, diğer katılımcıların memnuniyetlerine ilişkin olarak, çok memnunum $(\% 10,7)$, memnun değilim ( $\% 8,5)$, hiç memnun değilim $(\% 6,6)$ ve kararsızım $(\% 13,2)$ 
Ağızdan Ağıza İletişimin Tüketicilerin Beyaz Eşya Satın Alma Kararları Üzerindeki Etkisi... 1069

cevabını verdikleri, verilerden katılımcıların \%71,7'sinin mevcut beyaz eşyalarından memnun oldukları sonucu ortaya çıkmaktadır. Katılımcıların sahip oldukları beyaz eşyalarını satın alma ve değiştirme durumlarını ortaya koyan bulgulara bakıldığında "bozulan beyaz eşyanın tamir edilememesi durumunda" ifadesinin de dikkate alınmas1 durumunda, kat1lımc1ların \%71,1'nin ihtiyaçları doğrultusunda beyaz eşya satın aldıkları görülmüştür. Diğer taraftan katılımcıların $\% 24,8$ 'i sahip oldukları mevcut beyaz eşyanın bozulması durumunda tamir etmek yerine yenisini almak istedikleri belirlenmiştir. Bunlara ek olarak sadece \%4,1'i sahip oldukları mevcut beyaz eşyalarından daha üst bir model çıktığında satın alma eğilimi gösterdikleri anlaşılmaktadır. Ayrıca katılımcıların büyük bir kısmının $(\% 90,9)$ satın alma kararı aldıklarında satın alacakları beyaz eşyanın yeni (sıfır) olmasını, sadece \%9,1'nin ikinci el yani daha önce kullanılmış beyaz eşya olmasını tercih ettikleri görülmüştür.

Tablo 3: Ağızdan Ağıza İletişim Yoluyla Beyaz Eşya Satın Alma Tercihine Etki Eden Değişkenlere İlişkin Ortalamalar Tablosu

\begin{tabular}{|c|c|c|c|c|}
\hline \multirow{19}{*}{ 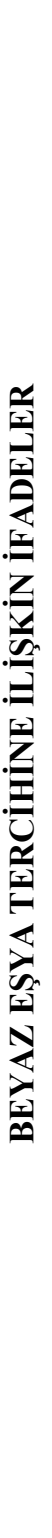 } & İFADELER & $\mathbf{N}$ & Ort. & St. Sp. \\
\hline & $\begin{array}{l}\text { K1- Beyaz eşya satın almak için tavsiye alırken akraba ve arkadaş çevreme daha } \\
\text { çok güvenirim. }\end{array}$ & 516 & 3,09 & 1,374 \\
\hline & K2- Beyaz eşya tercihimi belirlerken çevremdekiler bana tavsiyede bulundular. & 516 & 3,26 & 1,280 \\
\hline & K3- Beyaz eşya tercihimi belirlerken çevremdekilerden tavsiye isterim. & 516 & 3,30 & 1,336 \\
\hline & K4- Daha önce aynı beyaz eşyayı kullananların verdiği bilgilere güvenirim. & 516 & 3,50 & 1,261 \\
\hline & $\begin{array}{l}\text { K5- Beyaz eşya tercihimi belirlerken yakın arkadaşlarımın verdiği bilgilere daha } \\
\text { çok güvenirim. }\end{array}$ & 516 & 3,36 & 1,290 \\
\hline & $\begin{array}{l}\text { K6- Yakın çevremden aldığım tavsiyelere, diğer kaynaklara (internet vb) göre } \\
\text { daha çok güvenirim. }\end{array}$ & 516 & 3,09 & 1,368 \\
\hline & $\begin{array}{l}\text { K7- Tavsiye alacağım kişinin beyaz eşya konusunda bilgili ve tecrübeli olması } \\
\text { benim için önemlidir. }\end{array}$ & 516 & 3,73 & 1,270 \\
\hline & K8- Tavsiye alarak beyaz eşya tercihimi belirlediğimde pişman olmam. & 516 & 3,32 & 1,213 \\
\hline & $\begin{array}{l}\text { K9- Tanımadığım kişilerin beyaz eşya satın alma tercihimle ile ilgili yorumları } \\
\text { kararımı etkiler. }\end{array}$ & 516 & 2,87 & 1,361 \\
\hline & $\begin{array}{l}\text { K10- Kullanmadığım beyaz eşyalar ile ilgili çevremden gelen olumlu yorumları } \\
\text { başkalarına anlatırım. }\end{array}$ & 516 & 3,17 & 1,374 \\
\hline & $\begin{array}{l}\text { K11- Kullanmadığım beyaz eşyalar ile ilgili çevremden gelen olumsuz yorumları } \\
\text { başkalarına anlatırım. }\end{array}$ & 516 & 3,15 & 1,353 \\
\hline & $\begin{array}{l}\text { K12- Tercih ettiğim beyaz eşyadan memnun olduğumda akrabalarıma tavsiye } \\
\text { ederim. }\end{array}$ & 516 & 3,74 & 1,209 \\
\hline & $\begin{array}{l}\text { K13- Tercih ettiğim beyaz eşyadan memnun olduğumda arkadaşlarıma tavsiye } \\
\text { ederim. }\end{array}$ & 516 & 3,77 & 1,218 \\
\hline & $\begin{array}{l}\text { K14- Tercih ettiğim beyaz eşyadan memnun olduğumda yeri geldiğinde herkese } \\
\text { tavsiye ederim. }\end{array}$ & 516 & 3,67 & 1,284 \\
\hline & $\begin{array}{l}\text { K15- Tercih ettiğim beyaz eşyadan memnun kalmadığımda hiç kimseye tavsiye } \\
\text { etmem. }\end{array}$ & 516 & 3,48 & 1,469 \\
\hline & $\begin{array}{l}\text { K16- Tercih ettiğim beyaz eşya için tavsiye aldığım kişiler mutlaka bana } \\
\text { önerdikleri beyaz eşyanın kullanıcısı olmalıdır. }\end{array}$ & 516 & 3,64 & 1,269 \\
\hline & $\begin{array}{l}\text { K17- Bana önerilen beyaz eşyanın kullanıcısı olmayanların da tavsiyelerini } \\
\text { dikkate alırım. }\end{array}$ & 516 & 2,88 & 1,391 \\
\hline & $\begin{array}{l}\text { K18- Beyaz eşya tercihinde bulunmak isteyen çevremdeki kişilere (arkadaş, } \\
\text { akraba vb) kullanmakta olduğum beyaz eşyayı tavsiye ederim. }\end{array}$ & 516 & 3,46 & 1,231 \\
\hline
\end{tabular}




\begin{tabular}{|l|c|c|c|}
\hline K19- Tercih etmiş olduğum beyaz eşya ile ilgili konuşmayı severim. & 516 & 3,11 & 1,386 \\
\hline $\begin{array}{l}\text { K20- Tercih edeceğim beyaz eşyanın piyasada bilinen saygın bir marka olmas1 } \\
\text { benim için önemlidir. }\end{array}$ & 516 & 3,76 & 1,236 \\
\hline $\begin{array}{l}\text { K21- Tercih edeceğim beyaz eşyanın üreticisinin konusunda yeteri kadar } \\
\text { tecrübeli olması benim için önemlidir. }\end{array}$ & 516 & 3,76 & 1,212 \\
\hline $\begin{array}{l}\text { K22- Tercih etmiş olduğum beyaz eşya ilgili memnuniyetimi sosyal medyada } \\
\text { (facebook, twitter vb) ve bloglarda paylaşırım. }\end{array}$ & 516 & 2,36 & 1,423 \\
\hline $\begin{array}{l}\text { K23- Tercih etmiş olduğum beyaz eşya ilgili memnuniyetsizliğimi sosyal } \\
\text { medyada (facebook, twitter vb), bloglarda veya şikâyet sitelerinde paylaşırım. }\end{array}$ & 516 & 2,57 & 1,470 \\
\hline \begin{tabular}{l} 
K24- Çevremdeki insanlara satın aldığım ürünü almalarını öneriyorum. \\
\hline $\begin{array}{l}\text { K25- Ürünlerle ilgili eleştiriler ve görüşler satın alma kararı vermemde bana } \\
\text { yardımcı olur. }\end{array}$
\end{tabular} & 516 & 3,39 & 1,219 \\
\hline K26- Satın alacağım ürünü seçerken tavsiyeleri dikkate alırım. & 516 & 3,58 & 1,225 \\
\hline K27- Satın alacağım ürün hakkında önceden insanlarla konuşmayı severim. & 516 & 3,35 & 1,354 \\
\hline K28- Görüşünü aldığım kişi, daha önce ürünü satın almıştır. & 516 & 3,53 & 1,225 \\
\hline $\begin{array}{l}\text { K29- Yakınlarımın bilgisini, TV, internet, dergi, vb. kaynaklara göre daha } \\
\text { güvenilir bulurum. }\end{array}$ & 516 & 3,36 & 1,356 \\
\hline K30- Satın alma kararımı vermeden önce danışılacak en iyi kaynak çevremdir. & 516 & 3,53 & 1,312 \\
\hline
\end{tabular}

Ortalamalar tablosu (Tablo 3) incelendiğinde genel olarak katılımcıların beyaz eşya tercihinde ağızdan ağıza iletişimi etkileyen değişkenlerden K9, K17, K22 ve K23 değişkenlerine bazen katılım gösterdikleri diğer ifadelere ise genel olarak katılım gösterdikleri görülmektedir. Ankete cevap veren tüketicilerin beyaz eşya satın alma kararı almadan önce tavsiye konusunda arkadaş ve akraba gibi çevrelerinden gelen tavsiyeleri dikkate aldıkları tespit edilmiştir. Bu bağlamda yakın çevrelerinden tavsiye istedikleri, daha önce aynı model veya marka beyaz eşya kullanan tüketicilerin bilgilerine güvendikleri, memnuniyetlerini çevrelerine anlatıp tavsiyede bulundukları görülmektedir.

Katılımcıların satın alma kararı aldıkları markanın saygın, bilindik bir markanın olmasına yüksek katılım gösterdikleri tablodan anlaşılmaktadır. Bunun yanında genellikle tüketicilerin sahip oldukları beyaz eşyaya ilişkin memnuniyet ya da memnuniyetsizliklerini sosyal medya platformlarında, şikâyet sitelerinde veya bloglarda paylaşmadıkları görülmektedir. 
Tablo 4: Beyaz Eşya Tercihinde Ağızdan Ağıza İletişime Etki Eden Değişkenler ile Cinsiyet, Medeni Durum, Satın Alma Şekli Arasındaki Anlamlı Farka İlişkin T-Testi Analizi Sonuçları

\begin{tabular}{|c|c|c|c|c|c|c|}
\hline \multicolumn{2}{|c|}{ Değişkenler/Cinsiyet } & $\mathbf{N}$ & Ort. & St. Sp. & $\mathbf{t}$ & p \\
\hline \multirow{2}{*}{ K9 } & Erkek & 247 & 3,0040 & 1,37781 & \multirow{2}{*}{2,149} & \multirow{2}{*}{, $032 *$} \\
\hline & Kadin & 269 & 2,7472 & 1,33664 & & \\
\hline \multirow{2}{*}{ K12 } & Erkek & 247 & 3,8664 & 1,20059 & \multirow{2}{*}{2,279} & \multirow{2}{*}{, $023^{*}$} \\
\hline & Kadin & 269 & 3,6245 & 1,20799 & & \\
\hline \multirow[t]{2}{*}{ K14 } & Erkek & 247 & 3,8016 & 1,29301 & \multirow{2}{*}{2,164} & \multirow{2}{*}{, $031^{*}$} \\
\hline & Kadin & 269 & 3,5576 & 1,26721 & & \\
\hline \multirow{2}{*}{ K23 } & Erkek & 247 & 2,4130 & 1,42264 & \multirow{2}{*}{$-2,332$} & \multirow{2}{*}{, $020^{*}$} \\
\hline & Kadin & 269 & 1,7138 & 1,49995 & & \\
\hline \multicolumn{2}{|c|}{ Değişkenler/Medeni Durum } & $\mathbf{N}$ & Ort. & St. Sp. & $\mathbf{t}$ & p \\
\hline \multirow{2}{*}{$\mathrm{K} 21$} & Evli & 282 & 3,8652 & 1,15503 & \multirow{2}{*}{2,180} & \multirow{2}{*}{, $030^{*}$} \\
\hline & Bekâr & 234 & 3,6325 & 1,26761 & & \\
\hline \multirow{2}{*}{ K24 } & Evli & 282 & 3,3901 & 1,25004 & \multirow{2}{*}{2,288} & \multirow{2}{*}{, $023 *$} \\
\hline & Bekâr & 234 & 3,1282 & 1,34604 & & \\
\hline \multirow{2}{*}{ K26 } & Evli & 282 & 3,7092 & 1,14773 & \multirow[b]{2}{*}{2,576} & \multirow{2}{*}{, $010^{*}$} \\
\hline & Bekâr & 234 & 3,4316 & 1,29940 & & \\
\hline \multicolumn{2}{|c|}{ Değişkenler/Satın Alma Şekli } & $\mathbf{N}$ & Ort. & St. Sp. & $\mathbf{t}$ & $\mathbf{p}$ \\
\hline \multirow[b]{2}{*}{ K9 } & Bayiden sifir olarak & 469 & 2,8316 & 1,35534 & \multirow[b]{2}{*}{$-2,041$} & \multirow{2}{*}{, $042 *$} \\
\hline & İkinci el beyaz eşya satıcılarından & 47 & 3,2553 & 1,37474 & & \\
\hline \multirow{2}{*}{ K17 } & Bayiden sifir olarak & 469 & 2,8401 & 1,38444 & \multirow{2}{*}{$-2,159$} & \multirow{2}{*}{, $031^{*}$} \\
\hline & İkinci el beyaz eşya satıcılarından & 47 & 3,2979 & 1,39743 & & \\
\hline \multirow{2}{*}{ K22 } & Bayiden sifir olarak & 469 & 2,3070 & 1,40039 & \multirow{2}{*}{$-2,910$} & \multirow{2}{*}{, $004 * *$} \\
\hline & İkinci el beyaz eşya satıcılarından & 47 & 2,9362 & 1,53799 & & \\
\hline K23 & Bayiden sıfir olarak & 469 & 2,5288 & 1,45947 & & \\
\hline $\mathrm{K} 23$ & İkinci el beyaz eşya satıcılarından & 47 & 2,9787 & 1,52500 & $-2,001$ & , \\
\hline
\end{tabular}

${ }^{*} \mathrm{p}<0,05,{ }^{* *} \mathrm{p}<0,01$

Tablo 4 incelendiğinde araştırmaya katılan tüketicilerin cinsiyetleri ile beyaz eşya tercihinde ağızdan ağıza iletişimi etkileyen değişkenler arasında anlamlı bir farklılık olup olmadığına ilişkin yapılan t-testi analizi sonucunda, cinsiyet ile değişkenlerden K9, K12, K14 ve K23 değişkenleri arasında anlamlı farkın olduğu görülmüștür. Diğer değişkenlerde anlamlı farklılık bulunamamıştır. Anlamlı farklılıklardan, erkeklerin beyaz eşya satın alma kararı almadan önce kadınlara göre tercih etmiş oldukları beyaz eşyadan memnun kaldıklarında akrabalarına ve yeri geldiğinde herkese daha fazla tavsiye ettikleri sonucuna varmak mümkündür. Ayrıca erkeklerin kadınlara göre daha önce aynı beyaz eşyayı kullananların verdiği bilgilere daha çok güvendikleri ve tercih etmiş oldukları beyaz eşya ilgili duymuş oldukları memnuniyetsizliği sosyal medyada (facebook, twitter vb), bloglarda veya şikâyet sitelerinde paylaştıkları sonucuna varılmıştır.

Araştırmaya katılan tüketicilerin medeni durumları ile K21, K24 ve K26 değişkenleri arasında anlamlı bir farklılık olduğu gözlenmiştir. Ortalamalar incelendiğinde evlilerin bekârlara kıyasla tercih edecekleri beyaz eşyanın üretici işletmenin konusunda yeteri kadar tecrübeli olmasına daha fazla önem verdikleri anlaşılmaktadır. Bununla birlikte evli tüketicilerin bekâr tüketicilere nazaran satın almak istedikleri ürünleri seçerken tavsiyeleri daha çok dikkate aldıkları ve çevrelerindeki insanlara satın almış oldukları ürünü almaları konusunda daha fazla öneride bulundukları sonucuna ulaşmak mümkündür.

Ankete cevap veren tüketicilerin beyaz eşya satın alma şekilleri ile beyaz eşya tercihinde ağızdan ağıza iletişsimi etkileyen değişkenler arasında anlamlı bir farkın olup olmadığını ortaya koymak amacıyla yapılan t-testi analizi sonucunda K9, K17, K22 ve K23 değişkenleri arasında anlamlı bir fark olduğu ortaya çıkmıştır. Tüketicilerin beyaz eşya satın alırken çok yüksek düzeyde bayiden sıfır olarak satın almayı tercih ettikleri belirlenmiştir. Ortalamalar incelendiğinde ise beyaz eşyayı ikinci el beyaz eşya satıcılarından satın almak isteyen tüketicilerin, bayiden sıfır almayı tercih 
eden tüketicilere kiyasla memnuniyetlerini veya memnuniyetsizliklerini çeşitli sosyal medya platformlarında daha fazla paylaştıkları sonucu ortaya çıkmıştır. Ayrıca ikinci el beyaz eşya satın alma tercihinde bulunan tüketicilerin bayiden sıfır alan tüketicilere nazaran tanımadığı kişilerin vermiş olduğu tavsiyeleri daha çok dikkate aldıkları ve bununla birlikte ürünün kullanıcısı olmayan tüketicilerin de tavsiyelerine önem verdikleri sonucuna varılmıştır.

Tablo 5: Beyaz Eşya Tercihinde Ağızdan Ağıza İletişime Etki Eden Değişkenler ile E-Mail Kullanımı Arasındaki Anlamlı Farka İlişkin Bulgular

\begin{tabular}{|c|c|c|c|c|c|c|}
\hline \multicolumn{2}{|c|}{ Değişkenler/E-mail Kullanımı } & \multirow{2}{*}{$\frac{\mathbf{N}}{141}$} & \multirow{2}{*}{$\begin{array}{c}\text { Ort. } \\
2,7234\end{array}$} & \multirow{2}{*}{$\begin{array}{c}\text { St. Sp. } \\
1,503\end{array}$} & \multirow{2}{*}{$\mathbf{F}$} & \multirow[t]{2}{*}{ Sig. } \\
\hline \multirow{5}{*}{ K1 } & E-mailim yok/kullanmiyorum & & & & & \\
\hline & Günlük kontrol ediyorum. & 134 & 3,097 & 1,343 & \multirow{4}{*}{5,396} & \multirow{4}{*}{, $001 *$} \\
\hline & Haftalık kontrol ediyorum & 109 & 3,3394 & 1,226 & & \\
\hline & Aylık kontrol ediyorum & 132 & 3,2652 & 1,307 & & \\
\hline & Toplam & 516 & 3,0891 & 1,374 & & \\
\hline \multirow{5}{*}{ K4 } & E-mailim yok/kullanmıyorum & 141 & 2,7234 & 1,503 & \multirow{5}{*}{3,258} & \multirow{5}{*}{, $021 *$} \\
\hline & Günlük kontrol ediyorum. & 134 & 3,097 & 1,343 & & \\
\hline & Haftalık kontrol ediyorum & 109 & 3,3394 & 1,226 & & \\
\hline & Aylık kontrol ediyorum & 132 & 3,2652 & 1,307 & & \\
\hline & Toplam & 516 & 3,0891 & 1,374 & & \\
\hline \multirow{5}{*}{ K10 } & E-mailim yok/kullanmiyorum & 141 & 2,7234 & 1,503 & \multirow{5}{*}{2,8} & \multirow{5}{*}{, $039 *$} \\
\hline & Günlük kontrol ediyorum. & 134 & 3,097 & 1,343 & & \\
\hline & Haftalık kontrol ediyorum & 109 & 3,3394 & 1,226 & & \\
\hline & Aylik kontrol ediyorum & 132 & 3,2652 & 1,307 & & \\
\hline & Toplam & 516 & 3,0891 & 1,374 & & \\
\hline \multirow{5}{*}{ K17 } & E-mailim yok/kullanmıyorum & 141 & 2,7234 & 1,503 & \multirow{5}{*}{3,672} & \multirow{5}{*}{, $012 *$} \\
\hline & Günlük kontrol ediyorum. & 134 & 3,097 & 1,343 & & \\
\hline & Haftalık kontrol ediyorum & 109 & 3,3394 & 1,226 & & \\
\hline & Aylık kontrol ediyorum & 132 & 3,2652 & 1,307 & & \\
\hline & Toplam & 516 & 3,0891 & 1,374 & & \\
\hline \multirow{5}{*}{ K21 } & E-mailim yok/kullanmıyorum & 141 & 2,7234 & 1,503 & \multirow{5}{*}{3,017} & \multirow{5}{*}{, $030^{*}$} \\
\hline & Günlük kontrol ediyorum. & 134 & 3,097 & 1,343 & & \\
\hline & Haftalık kontrol ediyorum & 109 & 3,3394 & 1,226 & & \\
\hline & Aylik kontrol ediyorum & 132 & 3,2652 & 1,307 & & \\
\hline & Toplam & 516 & 3,0891 & 1,374 & & \\
\hline \multirow{5}{*}{$\mathrm{K} 25$} & E-mailim yok/kullanmıyorum & 141 & 2,7234 & 1,503 & \multirow{5}{*}{3,485} & \multirow{5}{*}{, $016^{*}$} \\
\hline & Günlük kontrol ediyorum. & 134 & 3,097 & 1,343 & & \\
\hline & Haftalık kontrol ediyorum & 109 & 3,3394 & 1,226 & & \\
\hline & Aylık kontrol ediyorum & 132 & 3,2652 & 1,307 & & \\
\hline & Toplam & 516 & 3,0891 & 1,374 & & \\
\hline
\end{tabular}

$* \mathrm{p}<0,05$

Tek yönlü varyans analizi sonucuna göre cevap veren katılımcıların e-mail kullanım düzeyleri ile beyaz eşya tercihinde ağızdan ağıza iletişimi etkileyen değişkenlerden $\mathrm{K} 1, \mathrm{~K} 4, \mathrm{~K} 10$, $\mathrm{K} 17, \mathrm{~K} 21$ ve K25 değişkenleri arasında anlamlı fark olduğu ortaya çıkmıştır. Anlamlı farkın nedenini ortaya koymak amacıyla yapılan Tukey testi sonucunda K10 ve K17 değişkenlerindeki anlamlı farkın e-maili olup, aylık kontrol edenler ile günlük kontrol edenler arasında olduğu görülmüsşür. Anlamlı farkın olduğu diğer değişkenlere bakıldığında ise anlamlı farkın e-maili olmayıp kullanmayanlar ile 
Ağızdan Ağıza İletişimin Tüketicilerin Beyaz Eşya Satın Alma Kararları Üzerindeki Etkisi... 1073

haftalık ve aylık kontrol edenler arasında meydana geldiği görülmüştür. Ortalamalar incelendiğinde, e-maili olup günlük kontrol edenler ile aylık kontrol edenlerin birbirlerine yakın düzeyde katılım gösterdikleri belirlenmiştir. E-mailini günlük kontrol edenlerin iletişime ve aynı zamanda internet üzerinden kullanım alanı olan fisıltı (buzz) ve viral ağızdan ağıza iletişime daha fazla önem verdiklerini ve açık olduklarını belirtmek mümkündür.

Tablo 6: Beyaz Eşya Tercihinde Ağızdan Ağıza İletişime Etki Eden Değişkenler ile Eğitim Durumu Arasındaki Anlamlı Farka İlişkin Bulgular

\begin{tabular}{|c|c|c|c|c|c|c|}
\hline \multicolumn{2}{|c|}{ Değișkenler/Eğitim Durumu } & \multirow{2}{*}{$\frac{\mathbf{N}}{77}$} & \multirow{2}{*}{$\frac{\text { Ort. }}{3,078}$} & \multirow{2}{*}{$\begin{array}{l}\text { St. Sp. } \\
1,4669\end{array}$} & \multirow[t]{2}{*}{$\mathbf{F}$} & \multirow[t]{2}{*}{ Sig. } \\
\hline \multirow{5}{*}{$\mathrm{K} 1$} & İlköğretim & & & & & \\
\hline & Lise & 140 & 3,007 & 1,4218 & \multirow{4}{*}{3,11} & \multirow{4}{*}{, $026^{*}$} \\
\hline & Ön lisans & 122 & 2,853 & 1,4005 & & \\
\hline & Lisans ve üstü & 177 & 3,322 & 1,2446 & & \\
\hline & Toplam & 516 & 3,089 & 1,3738 & & \\
\hline \multirow{5}{*}{$\mathrm{K} 2$} & İlköğretim & 77 & 3,208 & 1,2601 & \multirow{5}{*}{3,12} & \multirow{5}{*}{,026* } \\
\hline & Lise & 140 & 3,057 & 1,3559 & & \\
\hline & Ön lisans & 122 & 3,189 & 1,2749 & & \\
\hline & Lisans ve üstü & 177 & 3,48 & 1,2065 & & \\
\hline & Toplam & 516 & 3,256 & 1,2804 & & \\
\hline \multirow{5}{*}{$\mathrm{K} 3$} & İlköğretim & 77 & 3,234 & 1,3268 & \multirow{5}{*}{3,76} & \multirow{5}{*}{, $011^{*}$} \\
\hline & Lise & 140 & 3,057 & 1,4181 & & \\
\hline & Ön lisans & 122 & 3,246 & 1,3503 & & \\
\hline & Lisans ve üstü & 177 & 3,548 & 1,229 & & \\
\hline & Toplam & 516 & 3,297 & 1,3363 & & \\
\hline \multirow{5}{*}{ K5 } & İlköğretim & 77 & 3,416 & 1,3509 & \multirow{5}{*}{3,12} & \multirow{5}{*}{, $026^{*}$} \\
\hline & Lise & 140 & 3,314 & 1,3523 & & \\
\hline & Ön lisans & 122 & 3,107 & 1,2584 & & \\
\hline & Lisans ve üstü & 177 & 3,559 & 1,2099 & & \\
\hline & Toplam & 516 & 3,364 & 1,2904 & & \\
\hline \multirow{5}{*}{ K6 } & İlköğretim & 77 & 3,351 & 1,3354 & \multirow{5}{*}{5,55} & \multirow{5}{*}{, $001 * *$} \\
\hline & Lise & 140 & 2,757 & 1,3617 & & \\
\hline & Ön lisans & 122 & 3 & 1,4025 & & \\
\hline & Lisans ve üstü & 177 & 3,311 & 1,3097 & & \\
\hline & Toplam & 516 & 3,093 & 1,3678 & & \\
\hline \multirow{5}{*}{ K7 } & İlköğretim & 77 & 3,52 & 1,2525 & \multirow{5}{*}{4,48} & \multirow{5}{*}{, $004 * *$} \\
\hline & Lise & 140 & 3,629 & 1,3642 & & \\
\hline & Ön lisans & 122 & 3,59 & 1,3346 & & \\
\hline & Lisans ve üstü & 177 & 4,011 & 1,1078 & & \\
\hline & Toplam & 516 & 3,735 & 1,27 & & \\
\hline \multirow{5}{*}{ K9 } & İlköğretim & 77 & 3,247 & 1,2994 & & \\
\hline & Lise & 140 & 2,729 & 1,3877 & & \\
\hline & Ön lisans & 122 & 3,033 & 1,3419 & 3,97 &, $008 * *$ \\
\hline & Lisans ve üstü & 177 & 2,706 & 1,3457 & & \\
\hline & Toplam & 516 & 2,87 & 1,3613 & & \\
\hline & İlköğretim & 77 & 3,623 & 1,2465 & & \\
\hline & Lise & 140 & 3,7 & 1,2734 & & \\
\hline $\mathrm{K} 21$ & Ön lisans & 122 & 3,607 & 1,302 & 2,93 &, $033^{*}$ \\
\hline & Lisans ve üstü & 177 & 3,972 & 1,0522 & & \\
\hline & Toplam & 516 & 3,76 & 1,2118 & & \\
\hline $\mathrm{K} 25$ & İlköğretim & 77 & 3,364 & 1,2345 & 3,73 &, $011 *$ \\
\hline
\end{tabular}




\begin{tabular}{llccccc} 
& Lise & 140 & 3,236 & 1,2616 & & \\
& Ön lisans & 122 & 3,246 & 1,2082 & & \\
& Lisans ve üstü & 177 & 3,633 & 1,1558 & & \\
& Toplam & 516 & 3,393 & 1,2189 & & \\
\hline \multirow{5}{*}{ K27 } & İlköğretim & 77 & 3,481 & 1,2938 & & \\
& Lise & 140 & 3,2 & 1,4354 & & \\
& Ön lisans & 122 & 3,139 & 1,4335 & 3,25 &, $022^{*}$ \\
& Lisans ve üstü & 177 & 3,559 & 1,2239 & & \\
& Toplam & 516 & 3,351 & 1,3535 & & \\
\hline
\end{tabular}

$* \mathrm{p}<0,05, * * \mathrm{p}<0,01$

Tüketicilerin eğitim durumları ile değişkenler arasında anlamlı farkın olup olmadığının belirlenmesi amaciyla yapılan Anova analizi sonucunda, ankete cevap veren tüketicilerin eğitim düzeyleri ile değişkenlerden K1, K2, K3, K5, K6, K7, K9, K21, K25 ve K27 değişkenleri arasında anlamı ı fark ortaya çıkmıştır. Farkın nedeninin ortaya konması amacıyla yapılan Post- Hoc testlerinden Tukey testi sonucunda, anlamlı farkın eğitim düzeyi lisans-lisansüstü olan tüketiciler ile ön lisans ve lise olan tüketiciler arasında olduğu görülmüştür. Ayrıca K6 ve K7 değişkenlerinde anlamlı farkın ilköğretim ile lise, lisans-lisansüstü ile lise ve ilköğretim ile lisans-lisansüstü eğitim düzeyine sahip tüketiciler arasında olduğu belirlenmiştir.

Değişkenlere ilişkin ortalamalara bakıldığında, eğitim düzeyi lisans ve lisansüstü olan tüketicilerin eğitim düzeyi ilköğretim olan tüketicilere göre beyaz eşya satın alma kararı almadan önce yakın çevrelerinden gelen bilgileri daha çok önemsedikleri belirlenmiştir. Ayrıca, tavsiye verenin beyaz eşya konusunda bilgi ve tecrübe sahibi olması, tercih edilecek beyaz eşya markasının saygın ve yeteri kadar tecrübeli olması gerektiği konularına da önem verdikleri söylenebilir.

Tablo 7: Beyaz Eşya Tercihinde Ağızdan Ağıza İletişime Etki Eden Değişkenler ile Katılımcıların Meslekleri Arasındaki Anlamlı Farka İlișkin Bulgular

\begin{tabular}{|c|c|c|c|c|c|c|}
\hline \multicolumn{2}{|c|}{ Değișkenler/Meslek } & $\mathbf{N}$ & Ort. & St. Sp. & $\mathbf{F}$ & Sig. \\
\hline \multirow{6}{*}{ K1 } & Memur & 235 & 3,3191 & 1,28613 & \multirow{6}{*}{3,65} & \multirow{6}{*}{, $006 * *$} \\
\hline & İşçi & 58 & 3,0862 & 1,30161 & & \\
\hline & Özel Sektör Çalışanı & 51 & 2,7255 & 1,31268 & & \\
\hline & Serbest Meslek & 164 & 2,8963 & 1,48868 & & \\
\hline & Emekli & 8 & 2,625 & 1,40789 & & \\
\hline & Toplam & 516 & 3,0891 & 1,37375 & & \\
\hline \multirow{6}{*}{ K3 } & Memur & 235 & 3,4894 & 1,24503 & \multirow{6}{*}{2,451} & \multirow{6}{*}{, $045^{*}$} \\
\hline & İşçi & 58 & 3,2586 & 1,30532 & & \\
\hline & Özel Sektör Çalışanı & 51 & 3,1373 & 1,38592 & & \\
\hline & Serbest Meslek & 164 & 3,0976 & 1,41949 & & \\
\hline & Emekli & 8 & 3 & 1,60357 & & \\
\hline & Toplam & 516 & 3,2965 & 1,3363 & & \\
\hline \multirow{6}{*}{ K4 } & Memur & 235 & 3,5957 & 1,14092 & \multirow{6}{*}{3,087} & \multirow{6}{*}{, $016^{*}$} \\
\hline & İşçi & 58 & 3,7241 & 1,12067 & & \\
\hline & Özel Sektör Çalışanı & 51 & 3,0196 & 1,30369 & & \\
\hline & Serbest Meslek & 164 & 3,4451 & 1,41531 & & \\
\hline & Emekli & 8 & 3 & 1,30931 & & \\
\hline & Toplam & 516 & 3,4961 & 1,26106 & & \\
\hline
\end{tabular}

${ }^{*} \mathrm{p}<0,05, * * \mathrm{p}<0,01$

Tek yönlü varyans analizi sonucuna göre ankete cevap veren tüketicilerin sahip oldukları meslekleri ile beyaz eşya tercihinde ağızdan ağıza iletişimi etkileyen değişkenlerden K1, K3 ve K4 
Ağızdan Ağıza İletişimin Tüketicilerin Beyaz Eşya Satın Alma Kararları Üzerindeki Etkisi... 1075

arasında anlamlı fark ortaya çıkmıştır. Diğer değişkenlerde anlamlı fark oluşmamıştır. Tukey testi sonucunda her üç değişkende de anlamlı farkın memur olan tüketiciler ile serbest meslekle uğraşan, özel sektörde çalışan ve işçi olan tüketiciler arasında olduğu görülmüştür. Ortalamalar incelendiğinde, memur olan tüketiciler ile serbest meslek sahibi tüketicilerin yüksek düzeyde katılım gösterdikleri belirlenmiştir. Ayrıca söz konusu tüketicilerin yakın çevrelerinden aldıkları bilgileri önemsedikleri ve yakın çevrelerinden gelen bilgiler doğrultusunda beyaz eşya tercihinde bulunduklarını söylemek mümkündür.

Tablo 8: Beyaz Eşya Tercihinde Ağızdan Ağıza İletişime Etki Eden Değişkenler ile Katılımcıların Yaşları Arasındaki Anlamlı Farka İlişkin Bulgular

\begin{tabular}{|c|c|c|c|c|c|c|}
\hline \multicolumn{2}{|c|}{ Değişkenler/Yaş } & \multirow{2}{*}{$\frac{\mathbf{N}}{146}$} & \multirow{2}{*}{$\frac{\text { Ort. }}{3,3151}$} & \multirow{2}{*}{$\frac{\text { St. Sp. }}{1,3684}$} & \multirow[t]{2}{*}{$\mathbf{F}$} & \multirow[t]{2}{*}{ Sig. } \\
\hline \multirow{6}{*}{ K4 } & $25^{\prime}$ ten küçük & & & & & \\
\hline & $25-35$ aras1 & 222 & 3,6847 & 1,1842 & \multirow{5}{*}{5,045} & \multirow{5}{*}{, $001 * *$} \\
\hline & $36-45$ aras1 & 93 & 3,5376 & 1,1938 & & \\
\hline & $46-55$ aras1 & 46 & 3,3478 & 1,2332 & & \\
\hline & 56 ve üstü & 9 & 2,1111 & 0,928 & & \\
\hline & Toplam & 516 & 3,4961 & 1,2611 & & \\
\hline \multirow{6}{*}{ K6 } & $25^{\prime}$ ten küçük & 146 & 2,863 & 1,4124 & \multirow{6}{*}{2,52} & \multirow{6}{*}{, $040^{*}$} \\
\hline & $25-35$ aras1 & 222 & 3,2838 & 1,3738 & & \\
\hline & $36-45$ aras1 & 93 & 3,086 & 1,3159 & & \\
\hline & $46-55$ aras1 & 46 & 3,0217 & 1,2559 & & \\
\hline & 56 ve üstü & 9 & 2,5556 & 1,0138 & & \\
\hline & Toplam & 516 & 3,093 & 1,3678 & & \\
\hline \multirow{6}{*}{ K7 } & 25 'ten küçük & 146 & 3,5205 & 1,425 & \multirow{6}{*}{2,743} & \multirow{6}{*}{, $028^{*}$} \\
\hline & $25-35$ aras 1 & 222 & 3,8829 & 1,1747 & & \\
\hline & $36-45$ aras1 & 93 & 3,5699 & 1,2803 & & \\
\hline & $46-55$ aras1 & 46 & 3,9783 & 1,1053 & & \\
\hline & 56 ve üstü & 9 & 4 & 1 & & \\
\hline & Toplam & 516 & 3,7345 & 1,27 & & \\
\hline \multirow{6}{*}{ K8 } & $25^{\prime}$ ten küçük & 146 & 3,2055 & 1,2861 & \multirow{6}{*}{2,929} & \multirow{6}{*}{, $021 *$} \\
\hline & $25-35$ aras 1 & 222 & 3,4459 & 1,1822 & & \\
\hline & $36-45$ aras1 & 93 & 3,1398 & 1,1382 & & \\
\hline & $46-55$ aras 1 & 46 & 3,587 & 1,1465 & & \\
\hline & 56 ve üstü & 9 & 2,5556 & 1,3333 & & \\
\hline & Toplam & 516 & 3,3198 & 1,2134 & & \\
\hline \multirow{6}{*}{ K13 } & $25^{\prime}$ ten küçük & 146 & 3,5479 & 1,3395 & \multirow{6}{*}{2,941} & \multirow{6}{*}{, $020^{*}$} \\
\hline & $25-35$ aras 1 & 222 & 3,9054 & 1,1475 & & \\
\hline & $36-45$ aras1 & 93 & 3,8495 & 1,1511 & & \\
\hline & $46-55$ aras 1 & 46 & 3,7826 & 1,191 & & \\
\hline & 56 ve üstü & 9 & 3 & 1,118 & & \\
\hline & Toplam & 516 & 3,7674 & 1,2181 & & \\
\hline \multirow{6}{*}{ K18 } & 25'ten küçük & 146 & 3,3219 & 1,3943 & \multirow{6}{*}{2,534} & \multirow{6}{*}{, $040 *$} \\
\hline & $25-35$ aras 1 & 222 & 3,5991 & 1,1242 & & \\
\hline & $36-45$ aras1 & 93 & 3,5054 & 1,1192 & & \\
\hline & $46-55$ aras 1 & 46 & 3,2391 & 1,3027 & & \\
\hline & 56 ve üstü & 9 & 2,6667 & 1,2247 & & \\
\hline & Toplam & 516 & 3,4554 & 1,2307 & & \\
\hline K23 & $25^{\prime}$ ten küçük & 146 & 2,4658 & 1,4487 & 3,032 &, $017^{*}$ \\
\hline
\end{tabular}




\begin{tabular}{|c|c|c|c|c|c|c|}
\hline & $25-35$ aras 1 & 222 & 2,8063 & 1,49 & & \\
\hline & $36-45$ aras1 & 93 & 2,2473 & 1,3961 & & \\
\hline & $46-55$ aras1 & 46 & 2,5 & 1,4415 & & \\
\hline & 56 ve üstü & 9 & 2,1111 & 1,5366 & & \\
\hline & Toplam & 516 & 2,5698 & 1,4698 & & \\
\hline \multirow{6}{*}{$\mathrm{K} 25$} & 25 'ten küçük & 146 & 3,178 & 1,3271 & \multirow{6}{*}{3,726} & \multirow{6}{*}{, $005 * *$} \\
\hline & $25-35$ aras 1 & 222 & 3,626 & 1,1533 & & \\
\hline & $36-45$ aras1 & 93 & 3,28 & 1,1644 & & \\
\hline & $46-55$ aras1 & 46 & 3,217 & 1,1721 & & \\
\hline & 56 ve üstü & 9 & 3,222 & 0,9718 & & \\
\hline & Toplam & 516 & 3,393 & 1,2189 & & \\
\hline
\end{tabular}

${ }^{*} \mathrm{p}<0,05,{ }^{*} \mathrm{p}<0,01$

Tek yönlü varyans analizi sonucuna göre cevap veren tüketicilerin yaş aralıkları ile beyaz eşya tercihinde ağızdan ağıza iletişimi etkileyen değişkenlerden K4, K6, K7, K8, K13, K18, K23 ve K25 arasında anlamlı fark ortaya çıkmıştır. Diğer değişkenlerde anlamlı bir fark oluşmamıştır. Farkın nedeninin ortaya konması için yapılan Post- Hoc testlerinden Tukey testi sonucunda, 25 'ten küçük ile $25-35$ ve 56 ve üzeri, 36-45 yaş aralığında olan tüketiciler ile 56 ve üzeri ve $25-35$ yaş aralığında olan tüketiciler ile 56 ve üzeri yaşa sahip olan tüketiciler arasında anlamlı fark gerçekleşmiştir. Verilerden 25-35 yaş aralığına sahip tüketicilerin diğer yaş gruplarına nazaran daha çok aynı beyaz eşyayı kullanan tüketicilerin vermiş oldukları bilgilere güvendikleri ortalamalar tablosundan anlaşılmaktadır.

Yakın çevremden aldığım tavsiyelere, diğer kaynaklara (internet vb) göre daha çok güvenirim (K6) değişkenine bakıldığında oluşan anlamlı farkın, 25'ten küçük ile 25-35 yaş aralığı grubundan kaynaklandığı ortaya konmuştur. 25-35 yaş aralığında olan tüketicilerin yaşı 25 'ten küçük olan tüketicilere nazaran daha fazla yakın çevrelerinden almış oldukları tavsiyeleri diğer bilgi kaynaklarına tercih ettikleri anlaşılmaktadır.

Tablo 9: Beyaz Eşya Tercihinde Ağızdan Ağıza İletişime Etki Eden Değişkenler ile Tavsiye Arasındaki Anlamlı Farka İliş̧in Bulgular

\begin{tabular}{|c|c|c|c|c|c|c|}
\hline \multicolumn{2}{|c|}{ Değişkenler/Tavsiye } & $\mathbf{N}$ & Ort. & St. Sp. & $\mathbf{F}$ & Sig. \\
\hline \multirow{6}{*}{ K1 } & Arkadaşlarımın tavsiyesi & 118 & 3,3305 & 1,30125 & \multirow{6}{*}{3,994} & \multirow{6}{*}{, $003 * *$} \\
\hline & Akrabalarımın tavsiyesi & 116 & 3,3534 & 1,37211 & & \\
\hline & Uzman kişilerin tavsiyeleri & 159 & 2,8113 & 1,38331 & & \\
\hline & Sosyal medyadaki tavsiyeler & 30 & 3,0667 & 1,36289 & & \\
\hline & Satıcının tavsiyesi & 93 & 2,9355 & 1,36578 & & \\
\hline & Toplam & 516 & 3,0891 & 1,37375 & & \\
\hline \multirow{6}{*}{$\mathrm{K} 2$} & Arkadaşlarımın tavsiyesi & 118 & 3,4661 & 1,20315 & \multirow{6}{*}{3,363} & \multirow{6}{*}{, $010^{*}$} \\
\hline & Akrabalarımın tavsiyesi & 116 & 3,4483 & 1,23953 & & \\
\hline & Uzman kişilerin tavsiyeleri & 159 & 3,1698 & 1,27392 & & \\
\hline & Sosyal medyadaki tavsiyeler & 30 & 3,2 & 1,37465 & & \\
\hline & Satıcının tavsiyesi & 93 & 2,914 & 1,34047 & & \\
\hline & Toplam & 516 & 3,2558 & 1,28035 & & \\
\hline \multirow{4}{*}{$\mathrm{K} 3$} & Arkadaşlarımın tavsiyesi & 118 & 3,6525 & 1,15749 & \multirow{4}{*}{6,752} & \multirow{4}{*}{, $000 * *$} \\
\hline & Akrabalarımın tavsiyesi & 116 & 3,5862 & 1,20916 & & \\
\hline & Uzman kişilerin tavsiyeleri & 159 & 3,0755 & 1,4077 & & \\
\hline & Sosyal medyadaki tavsiyeler & 30 & 3,0667 & 1,55216 & & \\
\hline
\end{tabular}


Ağızdan Ağıza İletişimin Tüketicilerin Beyaz Eşya Satın Alma Kararları Üzerindeki Etkisi... 1077

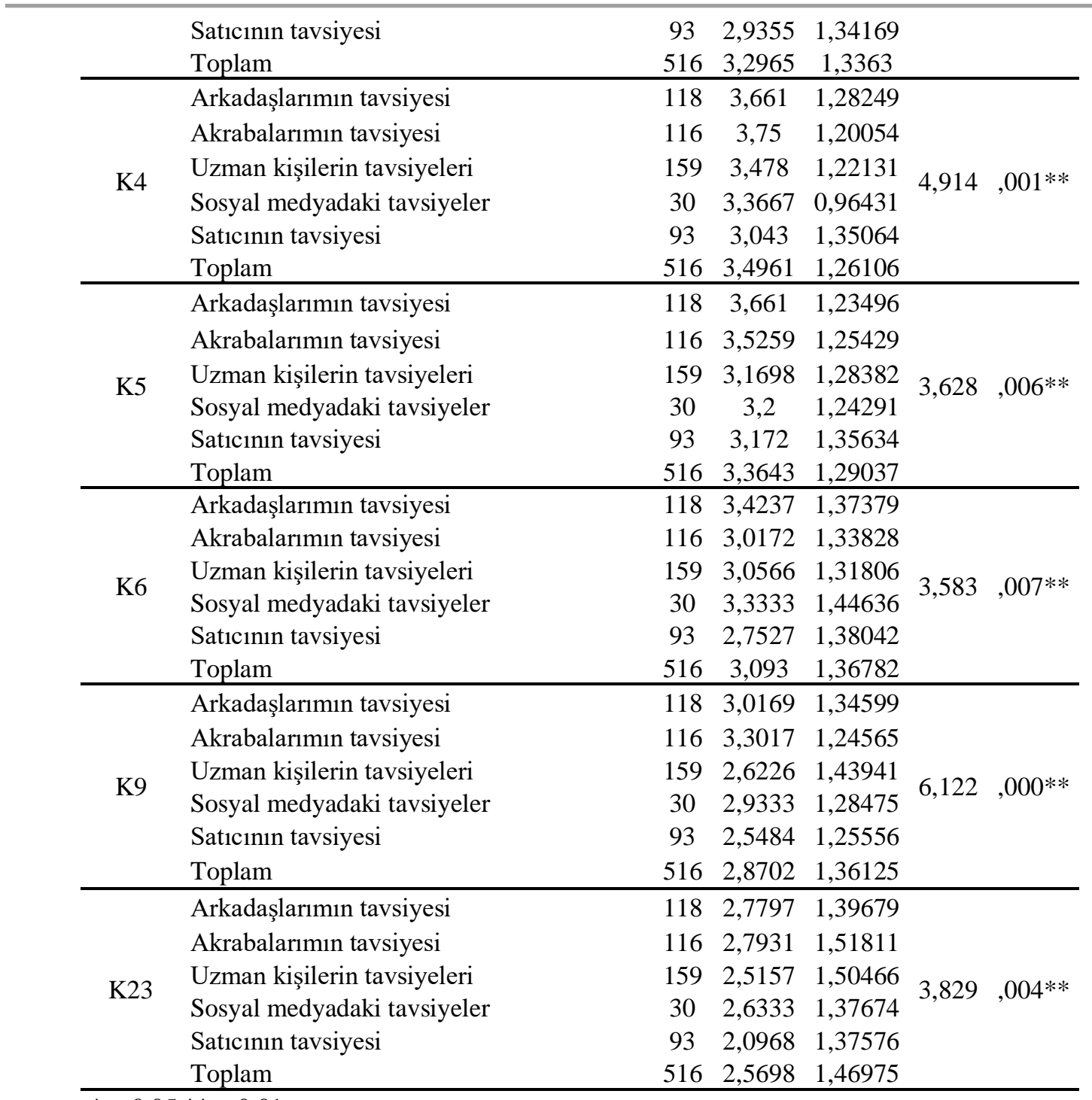

$* \mathrm{p}<0,05,{ }^{*} * \mathrm{p}<0,01$

Tek yönlü varyans analizine göre cevap verenlerin tercihinde kimlerden tavsiye aldıkları ile değişkenlerden K1, K2, K3, K4, K5, K6, K9, ve K23 değişkenleri arasında anlamlı farkın olduğu, diğer değişkenlerde ise anlamlı farkın ortaya çıkmadığı tespit edilmiştir. Farkın nedeninin tespiti için yapılan Tukey testi sonucunda K1 değişkenindeki farkın arkadaşlarımın tavsiyeleri ile uzman kişilerin verdiği tavsiyeler, akrabalarımın tavsiyeleri ile uzman kişilerin tavsiyeleri arasında gerçekleştiği görülmüştür. Cevap verenlerin sosyal medyadan alınan tavsiyelere ve satıcının vermiş olduğu tavsiyelere nazaran arkadaşlardan, akrabalardan ve uzman kişilerden gelen tavsiyelere daha fazla güvendikleri sonucuna varılmıştır. Anlamlı farkın ortaya çıktı̆̆ı diğer değişkenlerden K2, K3, $\mathrm{K} 4, \mathrm{~K} 5, \mathrm{~K} 6, \mathrm{~K} 9$ ve K23 değişkenlerinde ise söz konusu anlamlı farkın arkadaşlarımın ve akrabalarımın tavsiyeleri ile satıcı ve uzman kişilerin vermiş olduğu tavsiyeler arasında yapılan Tukey testi analizi sonucu verilerine göre gerçekleştiği görülmüştür. 
Tablo 10: Beyaz Eşya Tercihinde Ağızdan Ağıza İletişime Etki Eden Değişkenler ile Katılımcıların Mevcut Beyaz Eşya Satın Alma/Değiştirme Durumları Arasındaki Anlamlı Farka İlişkin Bulgular

\begin{tabular}{|c|c|c|c|c|c|c|}
\hline \multicolumn{2}{|c|}{ Değiş̧kenler/Satın Alma ve Değiştirme } & $\mathbf{N}$ & Ort. & St. Sp. & $\mathbf{F}$ & Sig. \\
\hline \multirow{5}{*}{$\mathrm{K} 1$} & Sadece ihtiyaç duyduğumda & 234 & 3,0427 & 1,37665 & \multirow{5}{*}{3,477} & \multirow{5}{*}{, $016^{*}$} \\
\hline & Mevcut beyaz eşyanın bozulması durumunda & 128 & 2,8906 & 1,34126 & & \\
\hline & $\begin{array}{l}\text { Bozulan beyaz eşyanın tamir edilememesi } \\
\text { durumunda }\end{array}$ & 133 & 3,3985 & 1,3311 & & \\
\hline & Daha üst bir model çıktığında & 21 & 2,8571 & 1,55839 & & \\
\hline & Toplam & 516 & 3,0891 & 1,37375 & & \\
\hline \multirow{5}{*}{$\mathrm{K} 2$} & Sadece ihtiyaç duyduğumda & 234 & 3,2051 & 1,30393 & \multirow{5}{*}{2,788} & \multirow{5}{*}{, $040^{*}$} \\
\hline & Mevcut beyaz eşyanın bozulması durumunda & 128 & 3,1406 & 1,23425 & & \\
\hline & $\begin{array}{l}\text { Bozulan beyaz eşyanın tamir edilememesi } \\
\text { durumunda }\end{array}$ & 133 & 3,5113 & 1,22237 & & \\
\hline & Daha üst bir model çıktığında & 21 & 2,9048 & 1,48003 & & \\
\hline & Toplam & 516 & 3,2558 & 1,28035 & & \\
\hline \multirow{5}{*}{ K4 } & Sadece ihtiyaç duyduğumda & 234 & 3,3846 & 1,26251 & \multirow{5}{*}{4,859} & \multirow{5}{*}{, $002 * *$} \\
\hline & Mevcut beyaz eşyanın bozulması durumunda & 128 & 3,3984 & 1,26951 & & \\
\hline & $\begin{array}{l}\text { Bozulan beyaz eşyanın tamir edilememesi } \\
\text { durumunda }\end{array}$ & 133 & 3,8421 & 1,16021 & & \\
\hline & Daha üst bir model çıktığında & 21 & 3,1429 & 1,45896 & & \\
\hline & Toplam & 516 & 3,4961 & 1,26106 & & \\
\hline \multirow{5}{*}{ K5 } & Sadece ihtiyaç duyduğumda & 234 & 3,3077 & 1,25648 & \multirow{5}{*}{3,159} & \multirow{5}{*}{, $024 *$} \\
\hline & Mevcut beyaz eşyanın bozulması durumunda & 128 & 3,2188 & 1,33362 & & \\
\hline & $\begin{array}{l}\text { Bozulan beyaz eşyanın tamir edilememesi } \\
\text { durumunda }\end{array}$ & 133 & 3,6466 & 1,23825 & & \\
\hline & Daha üst bir model çıktığında & 21 & 3,0952 & 1,51343 & & \\
\hline & Toplam & 516 & 3,3643 & 1,29037 & & \\
\hline \multirow{5}{*}{ K7 } & Sadece ihtiy & 234 & 3,6581 & 1,34364 & \multirow{5}{*}{3,905} & \multirow{5}{*}{, $009 * *$} \\
\hline & az eşyanın bozulması & 128 & 3,7813 & 1,22273 & & \\
\hline & $\begin{array}{l}\text { Bozulan beyaz eşyanın tamir edilememesi } \\
\text { durumunda }\end{array}$ & 133 & 3,9398 & 1,13324 & & \\
\hline & Daha üst bir model çıktığında & 21 & 3 & 1,26491 & & \\
\hline & Toplam & 516 & 3,7345 & 1,26999 & & \\
\hline \multirow{5}{*}{ K8 } & Sadece ih & 234 & 3,2521 & 1,25011 & \multirow{5}{*}{3,249} & \multirow{5}{*}{, $022 *$} \\
\hline & Mevcut beyaz eşyanın bozulması durumunda & 128 & 3,3047 & 1,15396 & & \\
\hline & $\begin{array}{l}\text { Bozulan beyaz eşyanın tamir edilememesi } \\
\text { durumunda }\end{array}$ & 133 & 3,5414 & 1,13826 & & \\
\hline & Daha üst bir model çıktığında & 21 & 2,7619 & 1,41084 & & \\
\hline & Toplam & 516 & 3,3198 & 1,21339 & & \\
\hline \multirow{5}{*}{ K12 } & Sadece iht & 234 & 3,7564 & 1,20285 & \multirow{5}{*}{3,53} & \multirow{5}{*}{, $015^{*}$} \\
\hline & Mevcut beyaz eşyanın bozulması durumunda & 128 & 3,7109 & 1,24326 & & \\
\hline & $\begin{array}{l}\text { Bozulan beyaz eşyanın tamir edilememesi } \\
\text { durumunda }\end{array}$ & 133 & 3,8647 & 1,12669 & & \\
\hline & Daha üst bir model çıktığında & 21 & 2,9524 & 1,35927 & & \\
\hline & Toplam & 516 & 3,7403 & 1,20935 & & \\
\hline \multirow{4}{*}{ K13 } & Sadece ihtiyaç duyduğumda & 234 & 3,7949 & 1,23287 & \multirow{4}{*}{3,637} & \multirow{4}{*}{, $013^{*}$} \\
\hline & Mevcut beyaz eşyanın bozulması durumunda & 128 & 3,7344 & 1,28274 & & \\
\hline & $\begin{array}{l}\text { Bozulan beyaz eşyanın tamir edilememesi } \\
\text { durumunda }\end{array}$ & 133 & 3,8797 & 1,08039 & & \\
\hline & Daha üst bir model çıktığında & 21 & 2,9524 & 1,24403 & & \\
\hline
\end{tabular}


Ağızdan Ağıza İletişimin Tüketicilerin Beyaz Eşya Satın Alma Kararları Üzerindeki Etkisi... 1079

\begin{tabular}{|c|c|c|c|c|c|c|}
\hline & Toplam & 516 & 3,7674 & 1,21806 & & \\
\hline \multirow{5}{*}{ K24 } & Sadece ihtiyaç duyduğumda & 234 & 3,1111 & 1,3055 & \multirow{5}{*}{3,336} & \multirow{5}{*}{, $019 *$} \\
\hline & Mevcut beyaz eşyanın bozulması durumunda & 128 & 3,2969 & 1,2881 & & \\
\hline & $\begin{array}{l}\text { Bozulan beyaz eşyanın tamir edilememesi } \\
\text { durumunda }\end{array}$ & 133 & 3,5489 & 1,23378 & & \\
\hline & Daha üst bir model çıktığında & 21 & 3,1429 & 1,49284 & & \\
\hline & Toplam & 516 & 3,2713 & 1,29975 & & \\
\hline \multirow{5}{*}{ K25 } & Sadece ihtiyaç duyduğumda & 234 & 3,3034 & 1,18911 & \multirow{5}{*}{2,784} & \multirow{5}{*}{, $040^{*}$} \\
\hline & Mevcut beyaz eşyanın bozulması durumunda & 128 & 3,3125 & 1,29049 & & \\
\hline & $\begin{array}{l}\text { Bozulan beyaz eşyanın tamir edilememesi } \\
\text { durumunda }\end{array}$ & 133 & 3,6541 & 1,11495 & & \\
\hline & Daha üst bir model çıktığında & 21 & 3,2381 & 1,54612 & & \\
\hline & Toplam & 516 & 3,3934 & 1,21889 & & \\
\hline \multirow{5}{*}{ K26 } & Sadece ihtiyaç duyduğumda & 234 & 3,4829 & 1,2403 & \multirow{5}{*}{2,726} & \multirow{5}{*}{, $044 *$} \\
\hline & Mevcut beyaz eşyanın bozulması durumunda & 128 & 3,5 & 1,31017 & & \\
\hline & $\begin{array}{l}\text { Bozulan beyaz eşyanın tamir edilememesi } \\
\text { durumunda }\end{array}$ & 133 & 3,8421 & 1,05774 & & \\
\hline & Daha üst bir model çıktığında & 21 & 3,5714 & 1,36277 & & \\
\hline & Toplam & 516 & 3,5833 & 1,22547 & & \\
\hline \multirow{5}{*}{ K27 } & Sadece ihtiyaç duyduğumda & 234 & 3,1667 & 1,3402 & \multirow{5}{*}{3,646} & \multirow{5}{*}{, $013 *$} \\
\hline & Mevcut beyaz eşyanın bozulması durumunda & 128 & 3,3672 & 1,40791 & & \\
\hline & $\begin{array}{l}\text { Bozulan beyaz eşyanın tamir edilememesi } \\
\text { durumunda }\end{array}$ & 133 & 3,6466 & 1,26249 & & \\
\hline & Daha üst bir model çıktığında & 21 & 3,4286 & 1,46872 & & \\
\hline & Toplam & 516 & 3,3508 & 1,35354 & & \\
\hline \multirow{5}{*}{ K30 } & Sadece ihtiyaç duyduğumda & 234 & 3,4103 & 1,30469 & \multirow{5}{*}{2,761} & \multirow{5}{*}{, $042 *$} \\
\hline & Mevcut beyaz eşyanın bozulması durumunda & 128 & 3,5156 & 1,35149 & & \\
\hline & $\begin{array}{l}\text { Bozulan beyaz eşyanın tamir edilememesi } \\
\text { durumunda }\end{array}$ & 133 & 3,797 & 1,22326 & & \\
\hline & Daha üst bir model çıktığında & 21 & 3,2857 & 1,52128 & & \\
\hline & Toplam & 516 & 3,531 & 1,31201 & & \\
\hline
\end{tabular}

$* \mathrm{p}<0,05,{ }^{* *} \mathrm{p}<0,01$

Tek yönlü varyans analizi sonuçlarına göre cevap veren tüketicilerin satın alma veya değiştirme durumları ile değişkenlerden K1, K2, K4, K5, K7, K8, K12, K13, K24, K25, K26, K27 ve K30 değişkenleri arasında anlamlı farkın olduğu, diğer değişkenlerde ise anlamlı farkın ortaya çıkmadığ tespit edilmiştir. Farkın nedeninin tespiti için yapılan Tukey testi sonucunda K1 ve K5 değişkenindeki farkın cevap verenlerin mevcut beyaz eşyalarının bozulması ve tamir edilememesi arasında gerçekleștiği görülmüștür. Söz konusu bu durumdan da cevap verenlerin yakın çevrelerinden gelen tavsiyelere önem verdikleri sonucuna varılmıştır. K4, K24, 25, K26, K27 ve K30 değişkenlerindeki anlamlı farkın ise beyaz eşyaya ihtiyaç duymaları ile mevcut beyaz eşyalarının tamir edilememesi durumlarından kaynaklandığı sonucuna ulaşılmışıır. K7, K8, K12 ve K13 değişkenleri incelendiğinde anlamlı farkın ortaya çıkmasında cevap veren katılımcıların ihtiyaçları halinde, mevcut beyaz eşyalarının bozulması ve tamir edilememesi ile mevcut beyaz eşyalarından daha bir üst model çıkması durumundan kaynaklandığı Tukey testi verilerinden anlaşılmıştır. 
Tablo 11: Beyaz Eşya Tercihinde Ağızdan Ağıza İletişime Etki Eden Değişkenler ile Katılımcıların Mevcut Beyaz Eşyalarına İlişkin Memnuniyetleri Arasındaki Anlamlı Farka İlişkin Bulgular

\begin{tabular}{|c|c|c|c|c|c|c|}
\hline \multicolumn{2}{|c|}{ Değişkenler/Memnuniyet Durumu } & \multirow{2}{*}{$\frac{\mathbf{N}}{34}$} & \multirow{2}{*}{$\frac{\text { Ort. }}{2,5}$} & \multirow{2}{*}{$\begin{array}{c}\text { St. Sp. } \\
1,50252\end{array}$} & \multirow[t]{2}{*}{$\mathbf{F}$} & \multirow{2}{*}{ Sig. } \\
\hline \multirow{6}{*}{$\mathrm{K} 1$} & Hiç memnun değilim & & & & & \\
\hline & Memnun değilim & 44 & 2,8636 & 1,32228 & \multirow{5}{*}{3,454} & \multirow{5}{*}{, $008 * *$} \\
\hline & Kararsızım & 68 & 2,8529 & 1,34125 & & \\
\hline & Memnunum & 315 & 3,2444 & 1,30186 & & \\
\hline & Çok memnunum & 55 & 3,0364 & 1,63258 & & \\
\hline & Toplam & 516 & 3,0891 & 1,37375 & & \\
\hline \multirow{6}{*}{ K4 } & Hiç memnun değilim & 34 & 2,8529 & 1,37361 & \multirow{6}{*}{3,437} & \multirow{6}{*}{, $009 * *$} \\
\hline & Memnun değilim & 44 & 3,7273 & 1,18839 & & \\
\hline & Kararsızım & 68 & 3,2941 & 1,30509 & & \\
\hline & Memnunum & 315 & 3,5492 & 1,21034 & & \\
\hline & Çok memnunum & 55 & 3,6545 & 1,36379 & & \\
\hline & Toplam & 516 & 3,4961 & 1,26106 & & \\
\hline \multirow{6}{*}{ K5 } & Hiç memnun değilim & 34 & 2,5294 & 1,26096 & \multirow{6}{*}{6,257} & \multirow{6}{*}{, $000 * *$} \\
\hline & Memnun değilim & 44 & 3,3182 & 1,41047 & & \\
\hline & Kararsızım & 68 & 3,1471 & 1,35233 & & \\
\hline & Memnunum & 315 & 3,546 & 1,18387 & & \\
\hline & Çok memnunum & 55 & 3,1455 & 1,47093 & & \\
\hline & Toplam & 516 & 3,3643 & 1,29037 & & \\
\hline \multirow{6}{*}{ K7 } & Hiç memnun değilim & 34 & 3,2353 & 1,55814 & \multirow{6}{*}{3,355} & \multirow{6}{*}{, $010^{*}$} \\
\hline & Memnun değilim & 44 & 3,3409 & 1,34585 & & \\
\hline & Kararsızım & 68 & 3,6618 & 1,24121 & & \\
\hline & Memnunum & 315 & 3,8667 & 1,18698 & & \\
\hline & Çok memnunum & 55 & 3,6909 & 1,39937 & & \\
\hline & Toplam & 516 & 3,7345 & 1,26999 & & \\
\hline \multirow{6}{*}{ K8 } & Hiç memnun değilim & 34 & 2,9118 & 1,19005 & \multirow{6}{*}{$\begin{array}{l}5 \\
5 \\
7,995 \\
3\end{array}$} & \multirow{6}{*}{, $003 * *$} \\
\hline & Memnun değilim & 44 & 2,9318 & 1,10806 & & \\
\hline & Kararsızım & 68 & 3,1618 & 1,34509 & & \\
\hline & Memnunum & 315 & 3,3873 & 1,15757 & & \\
\hline & Çok memnunum & 55 & 3,6909 & 1,31758 & & \\
\hline & Toplam & 516 & 3,3198 & 1,21339 & & \\
\hline \multirow{6}{*}{ K10 } & Hiç memnun değilim & 34 & 2,8235 & 1,44538 & \multirow{6}{*}{4,781} & \multirow{6}{*}{, $001 * *$} \\
\hline & Memnun değilim & 44 & 2,6591 & 1,23784 & & \\
\hline & Kararsızım & 68 & 2,9412 & 1,45461 & & \\
\hline & Memnunum & 315 & 3,3746 & 1,33283 & & \\
\hline & Çok memnunum & 55 & 2,9455 & 1,37999 & & \\
\hline & Toplam & 516 & 3,1744 & 1,37403 & & \\
\hline \multirow{5}{*}{ K12 } & Hiç memnun değilim & 34 & 3,5 & 1,39805 & & \\
\hline & Memnun değilim & 44 & 3,4318 & 1,24635 & & \\
\hline & Kararsızım & 68 & 3,3676 & 1,33723 & 3,998 &, $003^{* *}$ \\
\hline & Memnunum & 315 & 3,8921 & 1,13195 & & \\
\hline & Çok memnunum & 55 & 3,7273 & 1,19342 & & \\
\hline
\end{tabular}


Ağızdan Ağıza İletişimin Tüketicilerin Beyaz Eşya Satın Alma Kararları Üzerindeki Etkisi... 1081

\begin{tabular}{|c|c|c|c|c|c|c|}
\hline & Toplam & 516 & 3,7403 & 1,20935 & & \\
\hline \multirow{6}{*}{ K13 } & Hiç memnun değilim & 34 & 3,0588 & 1,49628 & \multirow{6}{*}{7,305} & \multirow{6}{*}{, $000 * *$} \\
\hline & Memnun değilim & 44 & 3,2273 & 1,25501 & & \\
\hline & Kararsızım & 68 & 3,6471 & 1,26685 & & \\
\hline & Memnunum & 315 & 3,9492 & 1,10757 & & \\
\hline & Çok memnunum & 55 & 3,7455 & 1,27973 & & \\
\hline & Toplam & 516 & 3,7674 & 1,21806 & & \\
\hline \multirow{6}{*}{ K14 } & Hiç memnun değilim & 34 & 3,1765 & 1,42426 & \multirow{6}{*}{2,659} & \multirow{6}{*}{, $032 *$} \\
\hline & Memnun değilim & 44 & 3,4318 & 1,18905 & & \\
\hline & Kararsızım & 68 & 3,5441 & 1,36517 & & \\
\hline & Memnunum & 315 & 3,8 & 1,22656 & & \\
\hline & Çok memnunum & 55 & 3,6182 & 1,40753 & & \\
\hline & Toplam & 516 & 3,6744 & 1,28418 & & \\
\hline \multirow{6}{*}{ K18 } & Hiç memnun değilim & 34 & 3 & 1,43548 & \multirow{6}{*}{3,831} & \multirow{6}{*}{, $004 * *$} \\
\hline & Memnun değilim & 44 & 3,2045 & 1,17294 & & \\
\hline & Kararsızım & 68 & 3,1471 & 1,29597 & & \\
\hline & Memnunum & 315 & 3,5714 & 1,18797 & & \\
\hline & Çok memnunum & 55 & 3,6545 & 1,17407 & & \\
\hline & Toplam & 516 & 3,4554 & 1,23066 & & \\
\hline \multirow{6}{*}{ K19 } & Hiç memnun değilim & 34 & 2,7941 & 1,45184 & \multirow{6}{*}{2,414} & \multirow{6}{*}{, $048 *$} \\
\hline & Memnun değilim & 44 & 2,9318 & 1,33639 & & \\
\hline & Kararsızım & 68 & 2,9706 & 1,33797 & & \\
\hline & Memnunum & 315 & 3,1143 & 1,39138 & & \\
\hline & Çok memnunum & 55 & 3,5818 & 1,3429 & & \\
\hline & Toplam & 516 & 3,1085 & 1,38643 & & \\
\hline \multirow{6}{*}{ K27 } & Hiç memnun değilim & 34 & 2,9412 & 1,6319 & \multirow{6}{*}{3,727} & \multirow{6}{*}{, $005^{* *}$} \\
\hline & Memnun değilim & 44 & 3,0227 & 1,28477 & & \\
\hline & Kararsizim & 68 & 3,0294 & 1,37103 & & \\
\hline & Memnunum & 315 & 3,5206 & 1,29995 & & \\
\hline & Çok memnunum & 55 & 3,2909 & 1,36995 & & \\
\hline & Toplam & 516 & 3,3508 & 1,35354 & & \\
\hline \multirow{6}{*}{ K28 } & Hiç memnun değilim & 34 & 3,2941 & 1,33778 & \multirow{6}{*}{2,655} & \multirow{6}{*}{, $032 *$} \\
\hline & Memnun değilim & 44 & 3,4545 & 1,0665 & & \\
\hline & Kararsızım & 68 & 3,1912 & 1,40635 & & \\
\hline & Memnunum & 315 & 3,6571 & 1,16062 & & \\
\hline & Çok memnunum & 55 & 3,4182 & 1,31503 & & \\
\hline & Toplam & 516 & 3,5291 & 1,2248 & & \\
\hline
\end{tabular}

$* \mathrm{p}<0,05, * * \mathrm{p}<0,01$

Tek yönlü varyans analizine göre cevap veren katılımcıların mevcut beyaz eşyalarından memnuniyetleri ile değişkenlerden K1, K4, K5, K7, K8, K10, K12, K13, K14, K18, K19, K27 ve K28 değişkenleri arasında anlamlı farkın olduğu, diğer değişkenlerde ise anlamlı farkın ortaya çıkmadığı tespit edilmiştir.

K1, K5 ve K7 değişkenleri incelendiğinde anlamlı farkın sadece hiç memnun değilim cevabı verenler ile memnunum cevabını tercih edenler arasında ortaya çıktığ 1 gözlenmiştir. Ortalamalar 
tablosundan memnun olanların hiç memnun olmayanlara göre hem tavsiye isteme hem de tavsiye verme değişkenlerine daha fazla önem verdikleri belirlenmiştir. K12, K27 ve K28 değişkenlerindeki anlamlı farkın karasızım ve memnunum arasında olduğu belirlenmiş olup, memnunum cevabını verenlerin kararsızım cevabını verenlerden daha yüksek düzeyde katılım gösterdikleri tespit edilmiştir. Memnun olan tüketicilerin satın almış olduğu ürün hakkında konuşmayı sevdiği ve bunu yakın çevresiyle paylaştığı sonucunu çıkarmak mümkündür. Tukey testi sonucu verilerinden K8 ve K13 değişkenlerindeki anlamlı farkın, hiç memnun değilim ve memnun değilim cevabını veren tüketiciler ile memnunum ve çok memnunum cevabını veren tüketiciler arasında olduğu görülmektedir. Cevap veren katılımcılardan memnun ve çok memnun olanların hiç memnun olmayan ve memnun olmayanlardan daha fazla ağızdan ağıza iletişim yolu ile memnun kaldıkları beyaz eşyayı tavsiye etmeye önem verdikleri söylenebilir. K14, K18 ve K19 değişkenlerde çıkan anlamlı farkın ise hiç memnun değilim, memnun değilim, kararsızım ve memnunun ile çok memnunum cevabını verenler arasında olduğu ortaya konmuştur.

\section{Sonuç ve Öneriler}

İşletmelerin başarısına katkı sağlayan en büyük pazarlama karması elemanlarından biri de tanıtım ve tutundurma faaliyetleridir. Artan rekabet koşullarında beyaz eşya sektöründe yer alan işletmeler, sektör içinde yer alan diğer rakip işletmelerden daha büyük bir pazar payına sahip olabilmek ve tüketiciler tarafından ilk tercih edilebilen işletme olabilmek adına çeşitli tanıtım ve tutundurma faaliyetleri gerçekleştirmektedirler. $\mathrm{Bu}$ açıdan işletmelerin herhangi bir ürünü üretip piyasaya sürmesi yeterli olmamaktadır. İşletmelerin üretmiş oldukları ürünlerin tüketiciler tarafından tercih edilebilir olması ve hedeflerine ulaşabilmesi adına üretilen ürünlerin tüketicilere çeşitli tutundurma faaliyetleri aracılığıyla duyurulması ve tanıtılması işletmelerin gelişimi ve büyümesi açısından büyük önem taşımaktadır.

Rekabetin giderek artmasıyla birlikte işletmelerin pazarlama stratejileri için ayırmış oldukları bütçeleri de büyümektedir. Tutundurma karması elemanlarından özellikle reklamın yüksek maliyetli olması işletmeleri farklı tutundurma faaliyetlerine yönlendirmektedir. Bu noktada öneminin giderek arttığı ağızdan ağıza iletişimin hem ucuz bir tanıtım ve tutundurma faaliyeti olması hem de işletmelerin üretmiş oldukları herhangi bir ürünün ağızdan ağıza iletişim kanalıyla hızla yayılması işletmeler için son derece önemli görülmektedir.

Genel olarak tüketiciler satın alma kararı vermeden önce, kimi zaman daha önce kullanıp deneyimledikleri mal veya hizmeti tercih ederken kimi zaman da bilgi sahibi olmadıkları bir mal veya hizmeti satın almak istediklerinde, kendilerince en güvenilir buldukları bilgi kaynağına başvurmaktadırlar. Bu noktada tüketiciler, yakın çevre olarak kabul ettikleri arkadaş ve akrabaları arasında daha önce bu mal veya hizmeti kullananlardan ya da tüketenlerden gelen bilgiler doğrultusunda hareket etmektedirler. Bazı tüketiciler ise satın almak istediği mal veya hizmetle ilgili uzman olduğuna inandıkları diğer tüketicilerin vermiş olduğu bilgiler ışığında karar vermektedirler.

Günümüzde iletişim konusundaki gelişmeler nedeni ile bilgiye erişim daha kolay hale gelmiştir. Böylelikle tüketicilerin günümüzde çok daha fazla bilinçlenmesini sağlamış olmasından dolayı işletmelerin klasik olarak adlandırılan pazarlama çalışmalarına güvenlerini yitirmişlerdir. $\mathrm{Bu}$ açıdan her sektörde olduğu gibi beyaz eşya sektöründe de tüketiciler arası iletişimden elde edinilen bilgiler tüketiciler tarafindan işletmelerin kontrolünde olan reklamlardan ve tanıtımlardan hem daha inandırıcı hem de daha güvenilir olarak görülmektedir. Bunun nedeni ise, satın alma kararını verirken işletmelerin çeşitli pazarlama çalışmalarına nazaran çevresindeki insanların daha dürüst, samimi, yapıcı ve satın alma kararı aldığı mal veya hizmetle ilgili daha deneyimli olmalarına inandıklarından ileri gelmektedir. Bu açıdan bakıldığında ağızdan ağıza iletişimin her sektörde olduğu gibi beyaz eşya sektöründe de önemli olduğunu gözler önüne sermektedir.

$\mathrm{Bu}$ çalışma ile tüketicilerin ağızdan ağıza iletişimin beyaz eşya satın alma kararlarına etkisi araştırılmıştır. Tüketicilerin satın alma tercihlerinde ağızdan ağıza iletişimden faydalanıp 
faydalanmadıkları ya da ne derecede faydalandıkları; satın alma karar sürecinde tavsiye alıp almadıkları ile genellikle kimlerden tavsiye aldıkları, memnun kaldıkları ürünleri tavsiye edip etmedikleri ve son olarak memnun kalmadıkları durumda ürününü satın aldıkları işletmeyi şikâyet edip etmedikleri belirlenmeye çalışılmıştır.

Çalışmanın amaçlarından biri, tüketicilerin demografik özellikleri ile ağızdan ağıza iletişim arasında anlamlı bir farklılık veya ilişkinin olup olmadığının araştırılmasıdır. Ağızdan ağıza iletişimin cinsiyet ve medeni durum ve tüketicilerin beyaz eşyalarını satın alma şekillerine göre farklılık gösterip göstermediğinin belirlenmesi amacıyla t-testi analizi yapılmıştır. Ayrıca yaş, eğitim, meslek, e-mail sosyal medya araçlarının kullanımı, tüketicilerin mevcut beyaz eşyalarına ilişkin memnuniyetleri, tüketicilerin kimlerden tavsiye aldıkları ve kaç kișiden tavsiye aldıklanı, mevcut beyaz eşya değiştirme veya satın alma durumları ve son olarak tüketici değerlendirmeye yönelik farklılık gösterip göstermediğinin belirlenmesi amacıyla tek yönlü varyans analizi uygulanmıştır. Yapılan t-testi ve tek yönlü varyans analizlerinin sonucunda ağızdan ağıza iletişim üzerinde tüketicilerin sahip oldukları demografik özelliklerinin anlamlı bir farklılığa neden olduğu sonucuna ulaşılmıştır.

Elde edilen verilerden, satın alma kararı vermiş olduğu beyaz eşyayı ikinci el beyaz eşya satıcılarından satın almak isteyen tüketiciler, satın alma tercihini bayiden sıfır alan tüketicilere kıyasla, memnuniyet veya memnuniyetsizliklerini çeşitli sosyal medya platformlarında daha fazla paylaştıkları belirlenmiştir. Ayrıca ikinci el beyaz eşya satın alma tercihinde bulunan tüketicilerin bayiden sıfır alan tüketicilere göre tanımadıkları kişilerin vermiş olduğu tavsiyeleri daha fazla dikkate aldıkları tespit edilmiștir. Bununla birlikte ikinci beyaz esya satın alma tercihinde bulunan katılımcıların satın almak istediği ürünün kullanıcısı olmayan tüketicilerin de tavsiyelerine önem verdikleri sonucuna varılmıştır. Evli olan katılımcıların bekârlara kıyasla tercih edecekleri beyaz eşyanın üretici işletmenin konusunda yeteri kadar tecrübeli olmasına daha fazla önem verdikleri belirlenmiştir. Bununla beraber evlilerin bekârlara göre satın almak istedikleri ürünleri seçerken tavsiyeleri daha çok dikkate aldıkları ve çevrelerindeki insanlara satın almış oldukları ürünü almaları konusunda daha fazla tavsiyede bulundukları tespit edilmiştir. Erkek katılımcıların, beyaz eşya satın alma kararı almadan önce kadınlara göre tercih etmiş oldukları beyaz eşyadan memnun kaldıklarında, akrabalarına ve yeri geldiğinde herkese daha fazla tavsiye ettikleri sonucuna varılmıştır. Ayrıca erkek katılımcıların kadın katılımcılara göre aynı beyaz eşyayı kullananların verdiği bilgilere daha çok güvendikleri belirlenmiştir. Bununla birlikte erkek katılımcıların tercih etmiş oldukları beyaz eşya ilgili duymuş oldukları memnuniyetsizliği sosyal medyada (facebook, instagram, twitter vb), bloglarda veya şikâyet sitelerinde paylaştıkları tespit edilmiştir (Tablo 4).

Araştırmanın bulguları (Tablo 6), beyaz eşya satın alma kararı almadan önce eğitim seviyesi yükseldikçe, yakın çevrelerden gelen bilgilerin daha yüksek düzeyde önemsendiği sonucunu ortaya koymuştur. Ayrıca, eğitim düzeyi yüksek olan katılımcıların, tavsiye aldığı tüketicinin beyaz eşya konusunda bilgi sahibi olması, tercih edilecek beyaz eşya markasının saygın ve yeteri kadar tecrübeli olması gerektiği konularına da daha çok önem verdikleri belirlenmiş̧ir.

Araştırmaya yüksek düzeyde katılım gösteren memur tüketiciler ile serbest meslek sahibi tüketicilerin (Tablo 7) yakın çevrelerinden aldıkları bilgileri önemsedikleri ve yakın çevrelerinden gelen bilgiler doğrultusunda satın alma kararı aldıkları gözlemlenmiştir.

Yapılan analizler sonucunda genel olarak, tüketicilerin ağızdan ağza iletişimden etkilenme seviyeleri bilgi alınan kişinin ürünle ilgili uzmanlık seviyesinin önemli bir etkiye sahip olduğu belirlenmiștir. Katılımcıların çoğunun yakın çevrelerinden, akraba ve arkadașlarından gelen bilgileri daha güvenilir bulduğu, bununla birlikte katılımcılar açısından bilgi alınan kişinin ürünle ilgili bilgi düzeyinin yüksek olmasının ve kullanıcı olarak deneyimli olmasının önemli olduğu tespit edilmiştir. Ayrıca katılımcıların satın aldıkları ürünle ilgili olarak kendilerinden daha uzman kişilere de başvurdukları sonucuna ulaşılmıştır. Öte yandan katılımcıların satın almış oldukları ürünler ile ilgili 
olarak memnuniyetlerini ya da memnuniyetsizlerini genellikle herhangi bir sosyal medya platformunda paylaşmadıkları sonucu elde edilmiştir.

Elde edilen veriler 1şı̆̆ında işletmelerin tüketicilerin beklenti ve ihtiyaçlarına karşılayacak ürünler üreterek müşteri memnuniyetine odaklanmaları gerektiği sonucuna ulaşılmıştır. Beyaz eşya sektöründe faaliyet gösteren işletmeler, yeni müşterilerin kazanılması ve mevcut müssteri kitlesinin elde tutulması konusunda klasik tutundurma ve tanıtım tekniklerinden olmayan ağızdan ağıza iletişime daha fazla önem vermeleri gerekmektedir. Maliyet bakımından da ekonomik bir iletişim aracı olan ağızdan ağıza iletişime gereken önemi veren işletmeleri, rekabet içerisinde olduğu rakiplerine göre bir adım daha öne taşıyacağı ve rekabet üstünlüğü sağlayacağ açıktır. Bu noktada "Her birey birer tavsiye kaynağıdır." cümlesinden hareketle işletme ve organizasyonların ağızdan ağıza iletişimden azami derecede faydalanmak istemeleri durumunda aşağıda belirtilen önerileri dikkate almaları gerektiği düşünülmektedir. Bu kapsamda; mal ve hizmetlerin etkin şekilde tanıtımının yapılabilmesi, yeni müşterilerin kazanılması ve sadık müşteri kitlesinin oluşturulması için işletmeler açısından önemli olan ağızdan ağıza iletişimin özellikle tanıtım ve tutundurma stratejilerine dâhil edilmesi önemli görülmektedir. Fikir liderleri aracılığıyla ve fikir liderlerinin tavsiye ve yönlendirmeleriyle işletmeye yeni müşteriler kazandırabilirler. Böylece işletmeler hedef pazarlarda fikir liderleri sayesinde işletmelerin tüketicilere iletmek istedikleri mesajları aktarabilirler. Olumsuz ağızdan ağıza iletişimi önlemek veya minimum seviyeye çekebilmek açısından hedef pazardaki bilgi akışını sürekli takip etmeleri ve olumlu ağızdan ağıza iletişimi doğuracak ortamlar oluşturabilirler.

Sektörde faaliyet gösteren işletmelerin mevcut müşterileri için önem taşıyan doğum günleri gibi özel günlerinde tebrik mesaj1, çiçek vb. hediyeler gönderilebilirler. Böylece mevcut müşterilerin işletme tarafından önemsendiklerinin bilinmesi sağlanabilir. Ayrıca yeni hizmetlerden müşterilerin haberdar olması amacıyla çeşitli tanıtım faaliyetleri ile haberdar edilerek mevcut müşteriler ile olan ilişkilerin daha da geliştirilmesi ve mevcut müşteriler vasıtasıyla hizmetlerin ağızdan ağıza iletişim yoluyla farklı tüketicilere tavsiye edilmesi sağlanabilir.

Genellikle beyaz eşya ürünlerinin uzun kullanım süreleri olduğundan tüketicilerin en çok önemsediği konulardan biri de satış sonrası hizmetlerdir. Bu açıdan hem satışlarını arttırmak hem de mevcut müşteri portföyünü arttırmak isteyen işletmelerin satış sonrası hizmetlerine büyük önem vermeleri gerekmektedir. Gereken önemi veren işletmeler, memnun müşteri kitlesinin oluşmasına zemin hazırlayacak olup, işletme hakkında olumlu ağızdan ağıza iletişimin oluşması sağlanabilir.

$\mathrm{Bu}$ araştırma çerçevesinde gelecekte yapılacak çalışmaların değişik sektörlerde ve daha büyük örneklemlerde gerçekleştirilmesinin yararlı olacağ düşünülmektedir. Araştırmanın konusunu beyaz eşya ürün gurubu oluşturmaktadır. Farklı ürün grupları farklı bir araştırma konusu olarak değerlendirilebilir. Çalışma ile hem beyaz eşya sektöründe faaliyet gösteren işletmelere hem de literatüre katkı sağlanabileceği düşünülmektedir. 
Ağızdan Ağıza İletişimin Tüketicilerin Beyaz Eşya Satın Alma Kararları Üzerindeki Etkisi... 1085

\section{Kaynakça}

Akçi, Y. ve Kılınç, K. (2016). Aktüel Ürün Perakendecilerine İlişkin Tüketici Görüşlerinin İncelenmesi. The Journal of Academic Social Science Studies. 8(49): 305-327.

Avcılar, M.Y. (2005). Kişisel Etki Kaynakları ve Ağızdan Ağıza İletişim Ağı. Niğde Üniversitesi İktisadi ve İdari Bilimler Dergisi. 1(2): 333-347.

Balaji, M.S., Roy, S.K. ve Lassar, W.M. (2017). Language Divergence in Service Encounters: Revisiting its Influence On Word-Of-Mouth. Journal of Business Research. 72: 210-213.

Balanche, D., Casalo, L.V. ve Flavian, C. (2010). Providing Online Public Services Successfully: The Role of Confirmation of Citizens' Expectations. International Review on Public and Nonprofit Marketing. 7(2): 167-184.

Berger, J. ve Iyengar, R. (2013). Communication Channels and Word of Mouth: How the Medium Shapes the Message. Journal of Consumer Research. 40(3): 567-579.

Buttle, F.A. (1998). Word of Mouth: Understanding and Managing Referral Marketing. Journal of Strategic Marketing. 6(3): 241-254.

Day, G.S. (1971). Attitude Change, Media and Word of Mouth. Journal of Advertising Research. 11(6): 31-40.

Derbaix, C. ve Vanhamme, J. (2003). Inducing Word of Mouth by Eliticing Surprise: A Pilot Investigation. Journal of Economic Psychology. 24: 99-116.

Godes, D. (2016). Product Policy in Markets With Word-Of-Mouth Communication. Management Science. 1-12.

Gürler, H.E. ve Erturgut, R. (2018). Hizmet Kalitesinin Müşteri Tatmini ve Ağızdan Ağıza İletişim Üzerindeki Etkisi: Havayolu Endüstrisinde Cinsiyet Temelli Bir Araştırma. İşletme Araştırmaları Dergisi - Journal of Business Research-Türk. 10(3): 229-253.

Ismail, A.R. ve Melewar, T.C. (2015). Binational Study Of The Impact Of Brand Image, Brand Personality And Brand Love On Word Of Mouth: The Case Of Fashion Brands İn UK And Switzerland. In: Robinson, Jr. L. (eds) Marketing Dynamism \& Sustainability: Things Change, Things Stay the Same Developments in Marketing Science: Proceedings of the Academy of Marketing Science. Springer, Cham.

Kitapci, O., Akdoğan, C. ve Dortyol, İ. T. (2014). The Impact of Service Quality Dimensions on Patient Satisfaction, Repurchase Intentions and Word-of-Mouth Communication in the Public Healthcare Industry. Procedia-Social and Behavioral Sciences. 148: 161-169.

Kılınç, K. (2017). Üniversite Öğrencilerinin Kuaför Tercihinde Ağızdan Ağıza İletişimin Etkisinin İncelenmesi. 3(12): 13-38.

Lang, B. (2015). Reconciling the Customer Satisfaction - Word of Mouth Relationship. In: Kubacki K. (eds) Ideas in Marketing: Finding the New and Polishing the Old. Developments in Marketing Science: Proceedings of the Academy of Marketing Science. Springer, Cham.

Lee, K. J. (2005). A Practical Method of Predicting Client Revisit Intention in a Hospital Setting. Health Care Management Review. 30(2): 157-167.

Liu, Y. (2006). Word of Mouth for Movies: Its Dynamics and Impact on Box Office Revenue. Journal of Marketing. 70(3): 74-89.

www.turkishstudies.net/social 
Odabaşı, Y. ve Oyman, M. (2006). Pazarlama İletişimi Yönetimi. İstanbul: MediaCat Yayınları.

Roy, S.K., Butaney, G., Sekhon, H. ve Butaney, B. (2014). Word-Of-Mouth And Viral Mar-keting Activity Of The On-Line Consumer: The Role Of Loyalty Chain Stages Theory. Journal of Strategic Marketing. 22(6): 1-19.

Patrick, M., Pateli, A. ve Giannakos, M.N. (2013). Why Are Users of Social Media Incli-ned to Word-of-Mouth? In: Douligeris C., Polemi N., Karantjias A., Lamersdorf W. (eds) Collaborative, Trusted and Privacy-Aware e/m-Services. I3E 2013. IFIP Ad-vances in Information and Communication Technology. V.399. Springer, Berlin: Heidelberg.

Silverman, G. (2001). The Secrets of Word of Mouth Marketing. New York: American Management Assocation.

Susskind, A.M. (2002). I Told You So!: Restaurant Customers' Word-of-Mouth Communication Patterns. Cornell Hospitality Quarterly. 43(2): 75.

Tayfun, A., Yıldırım, M. ve Kaş, L. (2013). Turistlerin Turistik Ürün Tercihlerinde Ağızdan Ağıza İletişimin Rolü: Yerli Turistler Üzerine Bir Araştırma. Journal of Tourism and Gastronomy Studies. 1(2): 26-38.

Uygun, M., Mete, S. ve Güner, E. (2014). Tüketicilerin Alışveriş Motivasyonları İle Ağızdan Ağıza İletişim Davranışları Arasındaki İlişkiler. Organizasyon ve Yönetim Bilimleri Dergisi. 6(1): $35-56$.

www.beysad.org.tr (2019). (Erişim Tarihi: 20.08.2019). 